\title{
Responses of a tundra system to warming using SCAMPS: a stoichiometrically coupled, acclimating microbe-plant-soil model
}

\author{
Seeta A. Sistla, ${ }^{1,3}$ Edward B. Rastetter, ${ }^{2}$ and Joshua P. Schimel ${ }^{1}$ \\ ${ }^{1}$ Department of Ecology, Evolution and Marine Biology, University of California, \\ Santa Barbara, California 93106 USA \\ ${ }^{2}$ The Ecosystems Center, Marine Biological Laboratory, Woods Hole, Massachusetts 02543 USA
}

\begin{abstract}
Soils, plants, and microbial communities respond to global change perturbations through coupled, nonlinear interactions. Dynamic ecological responses complicate projecting how global change disturbances will influence ecosystem processes, such as carbon (C) storage. We developed an ecosystem-scale model (Stoichiometrically Coupled, Acclimating Microbe-Plant-Soil model, SCAMPS) that simulates the dynamic feedbacks between aboveground and belowground communities that affect their shared soil environment. The belowground component of the model includes three classes of soil organic matter (SOM), three microbially synthesized extracellular enzyme classes specific to these SOM pools, and a microbial biomass pool with a variable $\mathrm{C}$-to-N ratio $(\mathrm{C}: \mathrm{N})$. The plant biomass, which contributes to the SOM pools, flexibly allocates growth toward wood, root, and leaf biomass, based on nitrogen $(\mathrm{N})$ uptake and shoot-to-root ratio. Unlike traditional ecosystem models, the microbial community can acclimate to changing soil resources by shifting its $\mathrm{C}: \mathrm{N}$ between a lower $\mathrm{C}: \mathrm{N}$, faster turnover (bacteria-like) community, and a higher $\mathrm{C}: \mathrm{N}$, slower turnover (fungal-like) community. This stoichiometric flexibility allows for the microbial $\mathrm{C}$ and $\mathrm{N}$ use efficiency to vary, feeding back into system decomposition and productivity dynamics. These feedbacks regulate changes in extracellular enzyme synthesis, soil pool turnover rates, plant growth, and ecosystem C storage. We used SCAMPS to test the interactive effects of winter, summer, and year-round soil warming, in combination with microbial acclimation ability, on decomposition dynamics and plant growth in a tundra system.

Over 50-year simulations, both the seasonality of warming and the ability of the microbial community to acclimate had strong effects on ecosystem C dynamics. Across all scenarios, warming increased plant biomass (and therefore litter inputs to the SOM), while the ability of the microbial community to acclimate increased soil $\mathrm{C}$ loss. Winter warming drove the largest ecosystem $\mathrm{C}$ losses when the microbial community could acclimate, and the largest ecosystem C gains when it could not acclimate. Similar to empirical studies of tundra warming, modeled summer warming had relatively negligible effects on soil C loss, regardless of acclimation ability. In contrast, winter and year-round warming drove marked soil C loss when decomposers could acclimate, despite also increasing plant biomass. These results suggest that incorporating dynamically interacting microbial and plant communities into ecosystem models might increase the ability to link ongoing global change field observations with macroscale projections of ecosystem biogeochemical cycling in systems under change.
\end{abstract}

Key words: Arctic tundra; biogeochemical cycles; climate warming; ecosystem model; extracellular enzymes; plant-soil-microbe feedbacks.

\section{INTRODUCTION}

Projecting how climate change will affect terrestrial biogeochemical feedbacks to the atmosphere is complicated by coupled, nonlinear interactions between organisms and their environment (Curiel Yuste et al. 2007, Waldrop and Harden 2008, Allison and Treseder 2011), and remains a challenge for global change modeling (Finzi et al. 2011, Treseder et al. 2011). Incorporating biological feedbacks into biogeochemical models has been an important step forward in characterizing

Manuscript received 5 December 2012; revised 21 March 2013; accepted 28 March 2013; final version received 7 May 2013. Corresponding Editor: H. A. L. Henry.

${ }^{3}$ E-mail: sistla@lifesci.ucsb.edu ecosystem responses to global change (Finzi et al. 2011). For example, developing decomposition models that include an explicit consideration of microbial physiology has allowed a more nuanced exploration of biological constraints on organic detritus turnover (Bunnell and Tait 1977, Bunnell et al. 1977, Fontaine et al. 2003, Schimel and Weintraub 2003, Moorhead and Sinsabaugh 2006), including capturing the transient stimulation of soil respiration that is often observed in long-term soil-warming experiments (Melillo et al. 2002, Eliasson et al. 2005, Allison et al. 2010).

Nonetheless, in contrast to the changing environmental and biotic conditions experienced in many field studies (Luo 2007), biogeochemical models generally 
assume a quasi steady state in the feedbacks among biological communities and ignore seasonal changes in biological interactions. Decomposers are often modeled as a uniform group, or implicitly through a decomposition rate constant (Schimel 2001); more mechanistically sophisticated decomposer models tend not to be coupled to primary productivity (Moorhead and Reynolds 1993, Allison et al. 2010). Conversely, plantfocused models tend to obscure feedbacks with the decomposer community, such as microbial response to changing plant inputs and the soil environment (Rastetter et al. 1991, Epstein et al. 2000). These assumptions might drive significant mis-estimation of ecosystem responses to environmental change that result from dynamic, coupled responses of decomposer and plant communities to perturbation, which are not adequately captured in current models. Quantifying how these interactions, encompassing community shifts, evolutionary adaptation, and physiological changes (Allison et al. 2010), influence ecosystem dynamics such as C sequestration remains a significant challenge.

The composition of soil microbial communities can directly influence nutrient availability, C stability, and soil organic matter (SOM) turnover (Zhang et al. 2005, Waldrop and Firestone 2006, Bardgett et al. 2008). Microbially synthesized extracellular enzymes catalyze the decomposition of polymeric detritus (Burns 1982, Allison et al. 2010); their synthesis is controlled by both substrate composition and microbial community structure. These links regulate feedbacks between plantderived soil inputs, the decomposer community, SOM cycling, and nutrient mineralization (Sinsabaugh et al. 2002). Oxidative enzymes target compounds with irregular and aromatic-dominant molecular structures (e.g., lignocellulose), while hydrolytic enzymes degrade SOM constituents with regularly arranged, hydrolysable bonds (e.g., cellulose and proteins [Cusack et al. 2010, Sinsabaugh 2010]). Oxidative enzyme activity tends to be negatively correlated with $\mathrm{N}$ availability and positively correlated with fungal dominance, while Cacquiring hydrolytic enzyme activity is positively associated with high $\mathrm{N}$ availability and bacterial dominance (Sinsabaugh et al. 2002, Waldrop and Zak 2006, Sinsabaugh 2010).

Because extracellular enzyme activity links SOM turnover to its decomposer community, as soil conditions or the microbial community change, the decomposition rates for different SOM pools will also change. These changes might in turn alter plant nutrient availability, and potentially, plant community structure (Ehrenfeld et al. 2005). Analogously, when plant communities shift (e.g., shrub encroachment, afforestation), changing litter inputs will affect decomposers and their activities (e.g., Resh et al. 2002, Liao and Boutton 2008, Brantley and Young 2010). For example, the addition of woody residues and other high $\mathrm{C}$ to $\mathrm{N}(\mathrm{C}: \mathrm{N})$ substrates can increase soil fungal/bacterial biomass ratios (F:B) and oxidative enzyme activity (Bossuyt et al.
2001, Brant et al. 2006), while $\mathrm{N}$ fertilization can decrease it (Frey et al. 2004, De Vries et al. 2006). Further, long-term warming in a tussock tundra system has been shown to increase both $\mathrm{F}$ : B dominance and $\mathrm{K}$ selected recalcitrant C-degraders, such as Actinobacteria (Deslippe et al. 2012). Therefore, if the microbial community becomes more fungal- or bacterial-dominated in composition, extracellular enzyme activity, SOM turnover dynamics, and plant nutrient availability are all expected to change.

To explore how linkages among plants, decomposers, and SOM might alter the plant-soil system's response to environmental changes, we developed a model that explicitly represents these dynamics (Fig. 1; Stoichiometrically Coupled, Acclimating Microbe-Plant-Soil model, SCAMPS). The microbial biomass is stoichiometrically flexible (Sistla and Schimel 2012). Its C:N shifts toward a more fungal (increasing average biomass $\mathrm{C}: \mathrm{N}$ ) or bacterial-like (decreasing average $\mathrm{C}: \mathrm{N}$ ) community in response to its soil environment (Strickland and Rousk 2010), which we term "microbial community acclimation." Microbial community acclimation alters microbial biomass turnover rate, nutrient use efficiency, and extracellular enzyme synthesis patterns in response to changing soil conditions. The plant community is flexible in its allocation of available $\mathrm{N}$ to wood, leaf, and root production, which span a wide range of $\mathrm{C}: \mathrm{N}$ and turnover rates, and can capture shifts between more graminoid- and woody-dominated communities. As the plant community responds to warming, inputs to the lignocellulose, C-rich holocellulose/carbohydrate, and $\mathrm{N}$-rich SOM pools vary. These three chemically defined soil detritus pools decompose at different rates, depending on microbial nutrient needs and extracellular enzyme synthesis patterns.

We note that the model does not include all characteristics that are important determinants in biogeochemical cycling, including physical processes such as hydrological connectivity, which can regulate enzyme catalytic activity (Oades 1984, Allison 2006), physical protection of substrates (Schimel and Schaeffer 2012), or the stabilization of SOM during microbial processing (Schmidt et al. 2011). Similarly, plant processes such as respiration and root exudation were not directly captured. Despite these deficits, the addition of a physiologically explicit microbial community into ecosystem models might increase predictive ability, especially in systems whose decomposer communities appear sensitive to environmental changes such as warming or nutrient addition (Knorr et al. 2005, Davidson and Janssens 2006).

We modeled the effects of warming on $\mathrm{C}$ and $\mathrm{N}$ feedbacks between plant, soil, and microbial biogeochemical cycling in an Arctic tundra system. Plant-soil feedbacks are strongest in extreme environments like tundra (Ehrenfeld et al. 2005), mediated in part through severe $\mathrm{N}$ and temperature limitation for both plant growth and decomposition (Mack et al. 2004, Lavoie et 


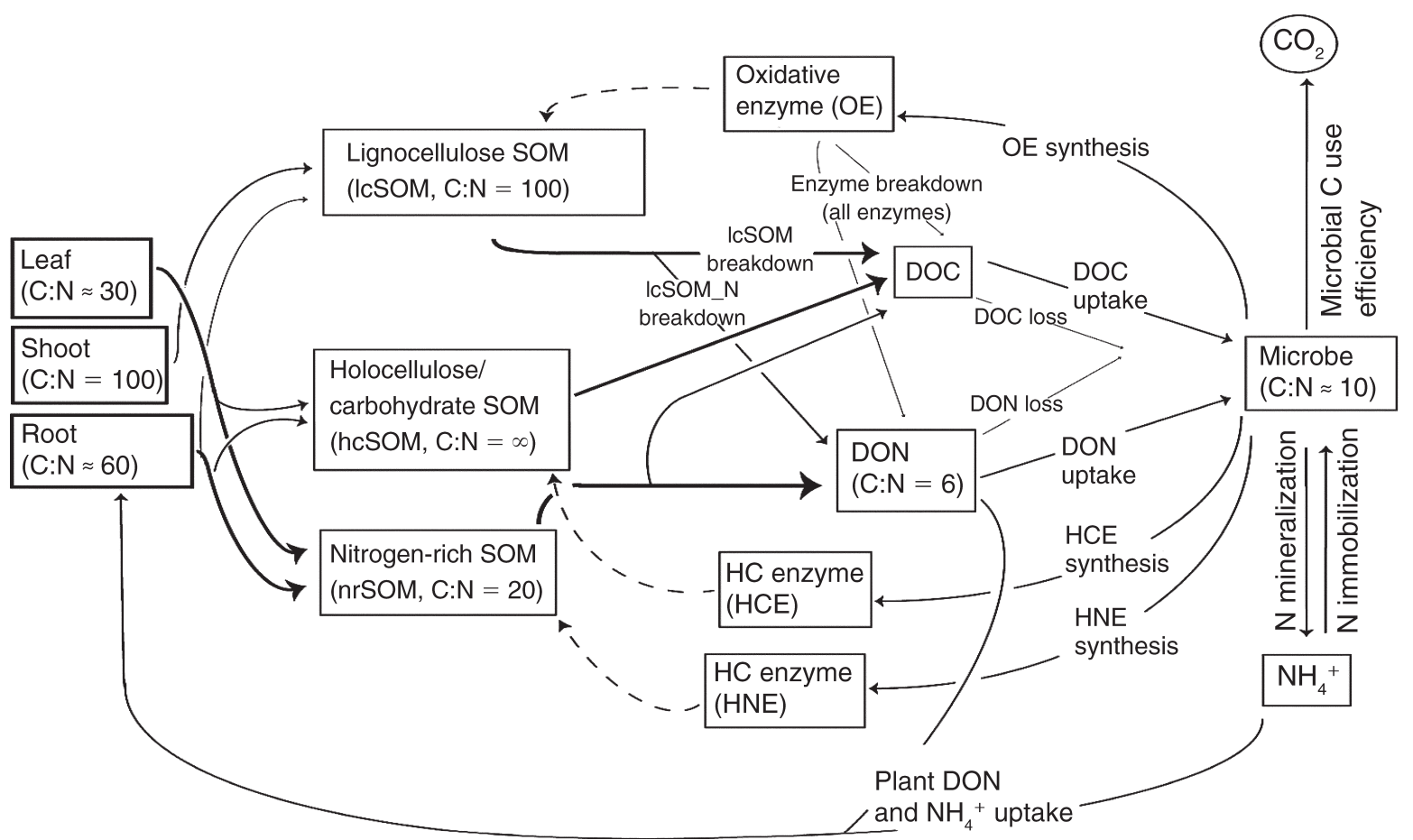

FIG. 1. A C-N linked ecosystem biogeochemical cycling model. Boxes represent pools of carbon $\left(\mathrm{C} ; \mathrm{g} / \mathrm{m}^{2}\right)$ or nitrogen $(\mathrm{N}$; $\mathrm{g} / \mathrm{m}^{2}$ ), and solid arrows represent the flow of material between pools or out of the system (not shown), with increasing width of the line representing the increasing relative contribution from one pool to another. Dashed arrows represent processes, such as the enzymatic breakdown of soil substrate. There are three classes of soil organic matter (SOM) and microbially produced extracellular enzymes targeting these SOM pools. The microbial pool acclimates between a more bacteria-like (lower biomass C:N target, faster turnover) and fungal-like community (higher $\mathrm{C}: \mathrm{N}$, slower turnover), in response to SOM environment. Plants dynamically allocate $\mathrm{N}$ to wood, root, and leaf growth, based on $\mathrm{N}$ uptake. The plant pools provide inputs to the SOM pools at a higher C:N than their standing biomass (via overwinter $\mathrm{N}$ retranslocation).

al. 2011, Natali et al. 2012, Sistla et al. 2012). Further, Arctic tundra systems are undergoing rapid climate warming that is dominated by winter warming (Sturm et al. 2005, Anisimov et al. 2007). This warming can promote significant biogeochemical changes, including increased decomposition leading to greater plant-available N (Chapin 1983, Hobbie 1996, Natali et al. 2011) and greater shrub dominance (Sturm et al. 2005, Weintraub and Schimel 2005, Elmendorf et al. 2012). Reflecting this confluence of positive and negative feedbacks among plant growth, community change, and decomposition on ecosystem C storage, Arctic warming is a source of large uncertainty in global climate models (Schuur et al. 2008, Koven et al. 2011).

We explored how the seasonality of warming relative to the acclimation potential of the microbial community affects multi-decadal scale biogeochemical feedbacks by addressing the following questions: (1) As soils warm, does the ability for decomposers to acclimate between fungal- vs. bacterial-dominated communities alter ecosystem C storage trajectories? (2) In tundra ecosystems, where peak plant productivity can be seasonally decoupled from peak decomposer activity (Wallenstein et al. 2009), how does the seasonality of simulated soil warming (summer, winter, or year-round) affect ecosystem $\mathrm{C}$ storage?

\section{Methods \\ Model description}

The model framework (Fig. 1) draws from the soil microbial $\mathrm{C}$ and $\mathrm{N}$ limitation model of Schimel and Weintraub (2003), the microbial physiology in response to warming model of Allison et al. (2010), the tundra soil organic C (SOC) model of Moorhead and Reynolds (1993), and the resource optimization model of Rastetter et al. $(1997,2001,2013)$. The model is driven by soil temperature $\left({ }^{\circ} \mathrm{C}\right)$ and allows inputs of DON and DOC from outside the system, which were set to 0 in our simulations. The specific process equations referred to in the text, the complete list of state functions, and process are found in Appendices A, B, and C, respectively. State variable, parameter, and process symbols can be found in Appendix B: Table B1 and Appendix C: Tables C1 and $\mathrm{C} 2$, respectively.

The SOM in the model system is separated into three chemically distinct pools: (1) A high $\mathrm{C}: \mathrm{N}$, recalcitrant pool that is dominated by lignocellulose and constituents bound to them (the lignocellulose pool); (2) 


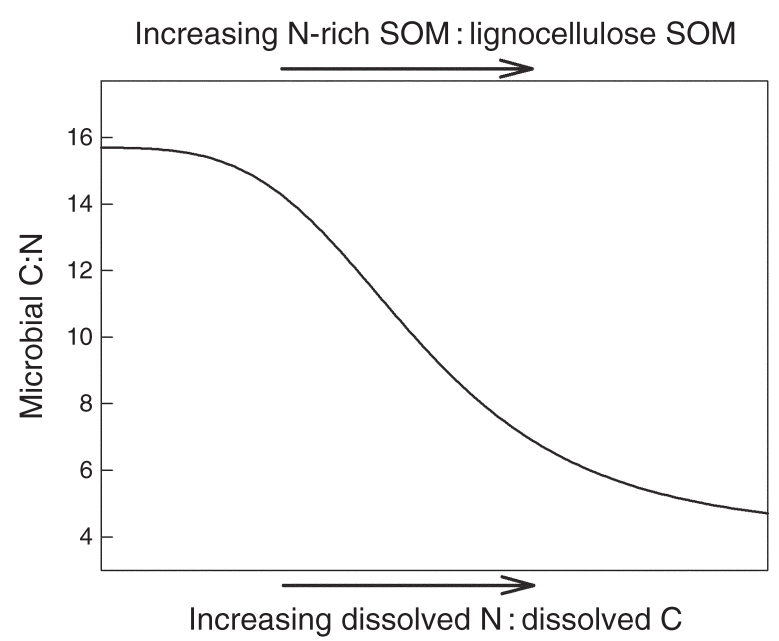

FIG. 2. A schematic of the relationship between soil conditions and microbial $\mathrm{C}: \mathrm{N}$. As the relative availability of dissolved $\mathrm{N}$ : dissolved $\mathrm{C}$ and $\mathrm{N}$-rich SOM : lignocellulose SOM increases, microbial $\mathrm{C}: \mathrm{N}$ will tend to move from a more fungallike community (relatively higher biomass $\mathrm{C}: \mathrm{N}$ ) to a more bacteria-like community (relatively lower biomass $\mathrm{C}: \mathrm{N}$ ).

holocellulose and carbohydrates; and (3) N-rich material. The soil pools are a coarse representation of the different components that make up organic soil horizon OM (Moorhead and Reynolds 1993), and are present in proportions similar to the tussock tundra soil active layer (Weintraub and Schimel 2003). Plant growth is regulated by available $\mathrm{N}$, time of year, and soil temperature. Plant resources are allocated to wood, roots, and leaves. As plant biomass senesces, it becomes litter and moves into SOM. Extracellular enzymes break down the SOM pools into biologically available forms. A different class of enzyme is synthesized by the microbial biomass to target each SOM pool; hydrolytic enzymes target holocellulose/carbohydrate C (HCE) and $\mathrm{N}$-rich substrates (HNE) while oxidative enzymes (OE) decompose the lignocellulose pool. Because of the strong $\mathrm{N}$ limitation of these ecosystems (Mack et al. 2004, Sistla et al. 2012), we assumed a closed N cycle with no $\mathrm{N}$ inputs or losses. Carbon enters the ecosystem only through net primary production, which is stoichiometrically constrained by plant tissue $\mathrm{C}: \mathrm{N}$ ratios and allocation patterns. The system loses $\mathrm{C}$ through microbial respiration and DOC leaching.

\section{Microbial physiology.-}

1. Microbial community acclimation.-The optimal $\mathrm{C}: \mathrm{N}$ set point for microbial biomass (qMicB*) adjusts toward a higher microbial $\mathrm{C}: \mathrm{N}$ (more fungal-like) when the ratio of N-rich SOM to lignocellulose SOM $(\mathrm{nrSOM} / \mathrm{lcSOM})$ or the ratio of dissolved $\mathrm{N}(\mathrm{DON}+$ $\mathrm{NH}_{4}{ }^{+}$) to dissolved organic $\mathrm{C}$ (DN/DOC) declines. The value of $\mathrm{qMicB}^{*}$ shifts toward lower microbial $\mathrm{C}: \mathrm{N}$ (more bacterial-like) as $\mathrm{nrSOM} / \mathrm{lcSOM}$ and $\mathrm{DN} / \mathrm{DOC}$ increase (Fig. 2; Appendix A: Eq. A.1). The actual microbial $\mathrm{C}: \mathrm{N}$ set point $(\mathrm{qMicB})$ acclimates toward the optimal value qMicB* asymptotically (Appendix A: Eq. A.2). In scenarios where qMicB* is fixed (i.e., a nonacclimating community), qMicB will also be constant. Under both acclimating and non-acclimating scenarios, the microbial biomass dynamically mineralizes and immobilizes $\mathrm{N}$ and $\mathrm{C}$ to attain the qMicB target.

2. Extracellular enzyme synthesis.-Both substrate availability and microbial nutrient demand regulate extracellular enzyme synthesis (Sinsabaugh et al. 2008). Microbial extracellular enzyme synthesis continually adjusts among the three enzyme classes depending on the $\mathrm{C}: \mathrm{N}$ of the microbial community. Synthesis of each enzyme is also stimulated by the abundance of substrate for that enzyme and inhibited by the products of the reaction mediated by that enzyme (Fig. 3).

Allocation of proportional synthesis effort toward the three extracellular enzyme classes is first partitioned between C-targeting hydrolytic enzymes (HCE) and the sum of oxidative (OE) and $\mathrm{N}$-targeting hydrolytic enzymes (HNE). The proportion of total enzyme synthesis that is OE plus HNE increases as the microbial $\mathrm{C}: \mathrm{N}$ ratio $(\mathrm{MC} / \mathrm{MN})$ and the ratio of lignocellulose to holocellulose (lcSOM/hcSOM) rise, and it declines as they drop (Appendix A: Eq. A.3). HCE synthesis increases as the microbial $\mathrm{C}: \mathrm{N}$ ratio and the ratio of lignocellulose to holocellulose decrease (Appendix A: Eq. A.4). Partitioning of enzyme synthesis between $\mathrm{OE}$ and HNE is determined by the ratios of $\mathrm{N}$-rich to lignocellulose SOM and of DN to DOC. OE synthesis increases as the ratio of lignocellulose to N-rich SOM $(\mathrm{lcSOM} / \mathrm{nrSOM})$ and $(\mathrm{DOC} / \mathrm{DN})$ increase (Appendix A: Eq. A5). HNE synthesis is the difference between synthesis effort allocated toward OE plus HNE minus the effort allocated toward OE synthesis (Appendix A: Eq. A6). Total extracellular enzyme synthesis increases exponentially with temperature and is proportional to microbial biomass; temperature-sensitive enzymes turnover occurs in proportion to their abundance, and the broken-down enzymes are added to the DOC and DON pools (Appendix A: Eqs. A.7-A.10 [Allison et al. 2010]).

3. Extracellular enzyme-mediated decomposition.SOM breakdown produces DOC and DON following kinetics that are Michaelis-Menten on SOM and firstorder on extracellular enzymes (Sinsabaugh and Moorhead 1994, Allison et al. 2010). The half saturation $\left(K_{\mathrm{m}(\mathrm{E})}\right)$ and rate $\left(V_{\max (\mathrm{E})}\right)$ both increase with temperature (Appendix A: Eqs. A.11-A.12 [Wallenstein et al. 2009, Allison et al. 2010]), and the $V_{\max }$ for the hydrolytic enzymes is greater than for the oxidative enzyme class. The subscript (E) represents the oxidative enzymes (OE), C-targeting hydrolytic enzymes (HCE), and the $\mathrm{N}$-targeting hydrolytic enzymes (HNE).We assumed that the SOM availability would not saturate enzyme reactions (Allison et al. 2010); therefore the decomposition $K_{\mathrm{m}}$ values were chosen to approximately match the range of SOM pool sizes. The DON pool has a constant C:N ratio (Appendix A: Eqs. A.13-A.17). 


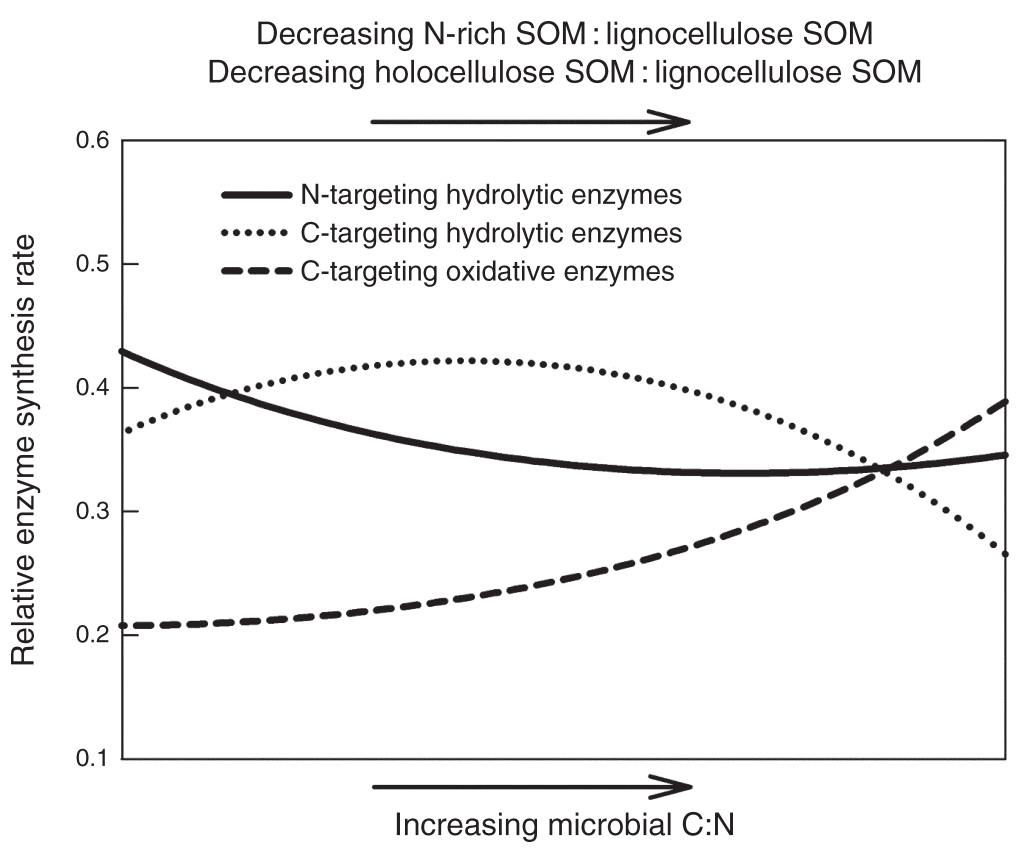

FIG. 3. A schematic of the relationship between soil conditions, microbial $\mathrm{C}: \mathrm{N}$, and allocation to extracellular enzyme synthesis. As the N-rich SOM : lignocellulose SOM substrate decreases and microbial C:N increases (moving toward a more fungallike community), the relative allocation toward $\mathrm{C}$-targeting oxidative enzymes will increase at the cost of C-and $\mathrm{N}$-targeting, hydrolytic enzymes. C-targeting hydrolytic enzyme allocation will tend to peak when neither fungal-like nor bacteria-like communities are strongly dominant in this model. N-targeting hydrolytic enzyme allocation peaks when the microbial community in most bacteria-like and labile SOM availability is greatest.

4. Microbial resource uptake.-Microbial DOC, DON, and $\mathrm{NH}_{4}^{+}$yield follow Michaelis-Menten kinetics (Appendix A: Eq. A.18), with a half-saturation parameter that increases with temperature (Appendix A: Eq. A.19), and a maximum yield proportional to microbial biomass that increases exponentially with temperature (Appendix A: Eq. A.20 [Mikan et al. 2002]). We assume $98 \%$ of each nutrient is available for microbial or plant uptake at a given time step (parameter $\Gamma$ ). Uptake is driven by a resource optimization scheme for plants developed by Rastetter et al. (Rastetter 2011, Rastetter et al. 2013). We assume that the microbes continuously adjust the allocation of uptake assets (uptake enzymes, energy expenditure, and other assets) to optimize the relative rates of resource acquisition to meet their stoichiometric needs. These uptake assets are represented in the model by an abstract variable we call "effort" $\left(\mathrm{Ef}_{i}\right.$ [Rastetter et al. 2013]). The subscript " $i$ " represents the resources DOC, DON, or $\mathrm{NH}_{4}^{+}$. Uptake for each resource increases linearly with the effort expended toward that resource. Resource requirement is calculated as the amount of the resource needed to maintain the microbial biomass and correct for any current stoichiometric imbalance; uptake in excess of requirement is used for biomass growth. C and $\mathrm{N}$ requirement thus accounts for $\mathrm{C}$ and $\mathrm{N}$ lost through turnover, mineralization, mortality, and enzyme synthesis (Appendix A: Eqs. A.21-A.22).
Allocation of effort toward substitutable resources is based on a marginal yield (i.e., incremental increase in uptake per incremental increase in effort expended). A marginal yield is calculated for each substitutable resource (C from DOC or DON, N from DON or $\mathrm{NH}_{4}^{+}$; Appendix A: Eqs. A.22-A.23), and these yields are used to partition the total requirement for $\mathrm{C}$ or $\mathrm{N}$ among these resources, with the greatest uptake effort for $\mathrm{C}$ and $\mathrm{N}$ allocated to the pool with the highest marginal yield (Appendix A: Eqs. A.25-A.27). Total effort is reallocated among resources to drive uptake rates toward a condition where the ratio of uptake to requirement is the same for all resources (Appendix A: Eqs. A.28-A.31; Appendix B: Eq. B.15 [Rastetter et al. 2013]).

5. Microbial growth and turnover.-Microbial growth $\left(\mathrm{Gr}_{\text {mic }}\right)$ is the minimum of the $\mathrm{C}\left(\mathrm{GC}_{\text {mic }}\right)$ or $\mathrm{N}\left(\mathrm{GN}_{\text {mic }}\right)$ growth potentials. $\mathrm{GC}_{\text {mic }}$ and $\mathrm{GN}_{\text {mic }}$ account for uptake of $\mathrm{C}$ and $\mathrm{N}$ and their loss through enzyme synthesis, mortality, and maintenance respiration, with the minimum of these growth potentials (or 0) equivalent to microbial growth (Appendix A: Eqs. A.32-A.34).

Microbial biomass $\mathrm{C}$ (MC) is lost to $\mathrm{CO}_{2}$ by growth, maintenance, and waste respiration. Growth respiration occurs only when the microbial biomass is growing, and it is not temperature sensitive (Appendix A: Eq. A.35). Maintenance respiration is a basal function of the microbial biomass (Appendix A: Eq. A.36). Waste respiration occurs when $\mathrm{MC} / \mathrm{MN}$ exceeds $\mathrm{qMicB}$ 
(Appendix A: Eq. A.37). Both maintenance and waste respiration are temperature sensitive, with the temperature coefficient increasing abruptly for soil temperatures below $0^{\circ} \mathrm{C}$ (Appendix A: Eq. A.38), following evidence that soil respiration Q10 is significantly greater below freezing in this system, which is likely associated with unfrozen water and diffusion limitations, rather than with microbial stress (Mikan et al. 2002). Microbial carbon-use efficiency (CUE) is defined as microbial growth/microbial C uptake (Appendix A: Eq. A.39).

The microbial mortality rate increases as microbial C:N declines (Appendix A: Eq. A.40), corresponding with a faster turnover rate as the community becomes more bacteria-like and slower turnover time as the community becomes more fungal-dominated (Six et al. 2006, Rousk and Bååth 2011). Microbial C and $\mathrm{N}$ biomass loss (death) occurs at a rate proportional to biomass (Appendix A: Eqs. A.40 and A.41). Dead MN is transferred to the $\mathrm{DON}$ pool, and dead $\mathrm{MC}$ is transferred to the DOC, DON, and holocellulose $\mathrm{C}$ SOM pool (Appendix A: Eqs. A.43 and A.44 [Allison et al. 2010]).

6. $\mathrm{N}$ mineralization.-Microbial $\mathrm{N}$ is released to the $\mathrm{NH}_{4}{ }^{+}$pool (Appendix A: Eq. A.45) when microbial C:N is lower than the microbial $\mathrm{C}: \mathrm{N}$ set point (qmicB). Because the model was closed to $\mathrm{N}$ inputs and losses, denitrification did not occur in these simulations.

Plant physiology.-During the growing season (defined as the period during which soil temperature exceeds $-1{ }^{\circ} \mathrm{C}$ and light conditions are adequate (day of year 74 to 274 , where day 1 is 1 January), plant biomass can take up both inorganic and organic N (DON, $\mathrm{NH}_{4}^{+}$ [Näsholm et al. 2009]). Plant N uptake occurs through the active root surface (Jackson et al. 1997). It follows Michaelis-Menten kinetics and is temperature sensitive (Appendix A: Eq. A.46). The plant uptake efficiency $\left(\chi_{n}\right.$, where $n=\mathrm{DON}$ or $\mathrm{NH}_{4}{ }^{+}$is greater for $\mathrm{NH}_{4}{ }^{+}$than for DON (Kielland 1994). Available $\mathrm{N}$ for plant growth is the sum of new plant $\mathrm{N}$ uptake and $\mathrm{N}$ retranslocated from senesced leaves (Appendix A: Eq. A.47).

1. Plant $N$ allocation.-Plants allocate $\mathrm{N}$ to shoots (wood + leaves) and roots based on the shoot to root ratio (shoot/root) relative to an ideal ratio (qshoot : root). Allocation of aboveground $\mathrm{N}$ to leaf and wood production is based on the proportion of leaf to wood biomass, relative to an ideal ratio $(\tau)$. Allocation of aboveground $\mathrm{N}$ to leaf relative to wood production declines as plant-available $\mathrm{N}$ increases (Appendix $\mathrm{A}$ : Eqs. A.48-A.51). We assumed that plant C growth is constrained primarily by N (Shaver and Chapin 1986, Mack et al. 2004); and the amount of $C$ accumulated therefore equals the sum of the $\mathrm{N}$ allocated toward leaf, wood, and root biomass times the $\mathrm{C}: \mathrm{N}$ of these tissues (Appendix A: Eqs. A.52-A.54). As plant $\mathrm{N}$ uptake increases, the standing woody biomass tends to increase over time more than leaf biomass, because its turnover rate is relatively slower, and greater $\mathrm{N}$ uptake favors an increased wood: leaf biomass set point. This increase in woody biomass associated with its slower turnover is only partly compensated by the lower allocation to the shoot relative to root biomass as woody tissues build up, generating the potential for increasing woody dominance with greater plant $\mathrm{N}$ uptake (Bret-Harte et al. 2002).

2. Plant litter loss and $N$ retranslocation.-At the end of the growing season, plants lose a proportion of leaf, root, and wood biomass as litter (Appendix A: Eqs. A.55-A.58). The litter is added to the SOM pools based on the stoichiometry and assumed chemical nature of the plant tissues relative to the stoichiometry and assumed chemical nature of the SOM pools (Moorhead and Reynolds 1993, Hobbie and Chapin 1998, Weintraub and Schimel 2003). Partitioning to lignocellulose, holocellulose, and N-rich SOM is $0 \%$, $40 \%$, and $60 \%$ for leaves; $100 \%, 0 \%$, and $0 \%$ for wood; and $12.5 \%, 65 \%$, and $22.5 \%$ for roots. All of the leaf litter $\mathrm{N}$ and $90 \%$ of the root litter $\mathrm{N}$ goes to the $\mathrm{N}$-rich $\mathrm{SOM}$, with the remaining root litter $\mathrm{N}$ released to the lignocellulose SOM pool (Appendix B: Eqs. B.1-B.5).

Plants can store $\mathrm{N}$ over the dormant period by retaining $\mathrm{N}$ during litter loss (the $\mathrm{C}: \mathrm{N}$ of leaf and root litter is greater than that of the live biomass [Hobbie 1996]). The stored $\mathrm{N}$ is remobilized during the onset of the growing season (approximate day of year 76 to 136; Appendix A: Eq. A.59). During this period, a proportion of the total stored $\mathrm{N}$ is made available to the plant for growth at each daily time step, with the remaining $\mathrm{N}$ remobilized on day of year 136 .

Parameterization and simulations.-Initial model conditions and parameters were calibrated (back calculated) for an Arctic tussock tundra ecosystem using literaturederived values (e.g., Shaver and Chapin 1991, Hobbie 1996, Hobbie and Chapin 1998, Chapin et al. 2008, Allison et al. 2010, Rastetter 2011) and from unpublished data from the Toolik Long-Term Ecological Research site Supplement (Arctic LTER Database [n.d.]).

1. Site description. - The model study site is moist acidic tundra (MAT). MAT vegetation is similar across the Alaskan North Slope (see Plate 1), northern Canada, and eastern Siberia, representing approximately $0.9 \times$ $10^{6} \mathrm{~km}^{2}$ of tussock tundra worldwide (Wein and Bliss 1974, Shaver and Chapin 1986, Oechel et al. 1993). The tussock-forming sedge Eriophorum vaginatum drives the formation of regular vegetation patterns, with the dominant deciduous shrub Betula nana growing between the tussocks (Chapin and Shaver 1989). Total vascular plant biomass is $\sim 385 \mathrm{~g} \mathrm{C} / \mathrm{m}^{2}$ and aboveground net primary production (NPP) is $\sim 80 \mathrm{~g} \mathrm{C} / \mathrm{m}^{2}$ (Shaver and Chapin 1991), with a modeled tundra NPP ranging from 34-423 g C $/ \mathrm{m}^{2}$ (Melillo et al. 1993). Root biomass ranges from 80 to $125 \mathrm{~g} \mathrm{C} / \mathrm{m}^{2}$ (McKane et al. 1997, Mack et al. 2004, Sullivan et al. 2007), with belowground NPP ranging from 30 to $80 \mathrm{~g} \cdot \mathrm{m}^{-2} \cdot \mathrm{yr}^{-1}$ (Nadelhoffer et al. 2002, Sullivan et al. 2007).

Mean air temperature during the June-August growing season is $9.3^{\circ} \mathrm{C}$, mean annual temperature is 


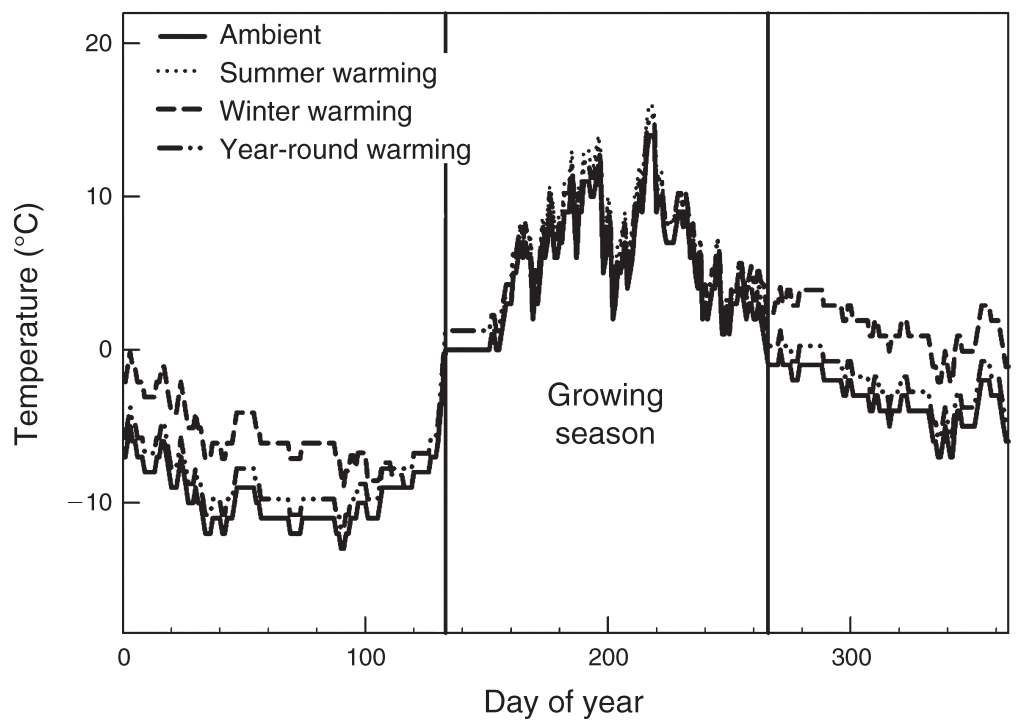

FIG. 4. Daily average soil temperature at $\sim 10 \mathrm{~cm}$ depth over a year time course, and three warming scenarios (summer, winter, year-round). Soil temperature repeats yearly in the model. In order to simulate Arctic climate change, the optimized warming scenarios were run for 50 years. Vertical bars demark the plant growing season, when ambient soil temperatures exceed $-1{ }^{\circ} \mathrm{C}$. In the summer warming scenario, soil temperature is increased to $2^{\circ} \mathrm{C}$ over ambient in 5-day increments in June (day of year 152-175) and decreased to ambient over an analogous period in September (day of year 219-243). In the winter warming treatment, the soil temperature is increased to $4.89^{\circ} \mathrm{C}$ over ambient in an analogous period from plant senescence in September (day of year 249-283) and returned to the baseline conditions in late April, within the period of the onset of new plant growth (day of year 91-115). Yearround warming is modeled as $1.24^{\circ} \mathrm{C}$ over ambient conditions.

$-12^{\circ} \mathrm{C}$, and total precipitation averages $318 \mathrm{~mm} / \mathrm{yr}$ (Shaver and Laundre 2010). Soil in MAT ecosystems is classified as coarse-loamy, mixed, acidic, gelic Typic Aquiturbels (Romanovsky et al. 2007). The maximum depth of thaw ranges from 30 to $50 \mathrm{~cm}$ (Giblin et al. 1991). Typically, the organic horizon is $30-50 \mathrm{~cm}$ thick and is underlain by silty mineral soil. The organic horizon contains $>4000 \mathrm{~g} \mathrm{C} / \mathrm{m}^{2}$ (Giblin et al. 1991, Mack et al. 2004, Sistla et al. 2013), while total C storage within the underlying permafrost is $\sim 10000-26400 \mathrm{~g} \mathrm{C} /$ $\mathrm{m}^{2}$ (Kuhry et al. 2009, Tarnocai et al. 2009). Estimated annual tundra soil respiration ranges between 53 and $286 \mathrm{~g} \mathrm{C} \cdot \mathrm{m}^{-2} \cdot \mathrm{yr}^{-1}$ (Raich and Schlesinger 1992, Oechel et al. 1993).

2. Climate-warming simulations.-Soil temperature follows the daily average of a long-term Arctic soil temperature data set recorded at $10 \mathrm{~cm}$ depth at the Arctic LTER site for 2002 (Arctic LTER Database [n.d.], Shaver and Laundre 2010), and we repeated the same year of temperature data for all 50 years of the control simulations to remove year-to-year variation from confounding the analysis. To simulate plausible Arctic climate change scenarios (Sturm et al. 2005, Alley et al. 2007), summer, winter, and year-round soil warming simulations were run for 50 years after being spun up to equilibrium (Fig. 4). We chose 50-year simulations because manipulative ecosystem experiments have been able to capture shifts in plant and microbial community structure within this time period (e.g., Frey et al. 2004, Zhang et al. 2005, Rinnan et al. 2007, Deslippe et al. 2012).

The temperature changes in the simulations were normalized so that the apparent Q10 effect on microbial respiration and resource uptake (summed over a year) was equivalent among all warming scenarios. In the summer warming scenario, the soil temperature was increased to $2^{\circ} \mathrm{C}$ over ambient, ramping up in increments of $0.4^{\circ} \mathrm{C}$ every fifth day from 1 through 25 June (day of year 152-176) and decreased to ambient in $0.4^{\circ} \mathrm{C}$ increments over an analogous period in August (day of year 219-243). In the winter warming treatment, the soil temperature was increased to $4.89^{\circ} \mathrm{C}$ over ambient in $0.978^{\circ} \mathrm{C}$ increments over an analogous period from plant senescence in September (day of year 249-273) and returned to the baseline conditions in late April, within the period of the onset of plant growth (day of year 91115). The latter scenario reflects that winter and shoulder season (winter to spring and summer to fall transition) temperatures are predicted to warm disproportionately in tundra systems (Sturm et al. 2005, Schuur et al. 2008). Year-round warming was modeled as $1.24^{\circ} \mathrm{C}$ over ambient conditions.

3. Microbial acclimation potential.-We tested whether the microbial community's ability to shift its composition and stoichiometry was important to controlling overall ecosystem $\mathrm{C}$ balance in response to warming by running the model when: (1) the microbial biomass had a constant C:N set point of 10 , and (2) 
TABLE 1. Yearly average of soil and plant $\mathrm{C}$ pools $\left(\mathrm{g} \mathrm{C} / \mathrm{m}^{2}\right)$ following 50 years of warming under conditions when microbes could (acclimating) and could not (non-acclimating) adjust their $\mathrm{C}: \mathrm{N}$ set point.

\begin{tabular}{|c|c|c|c|c|c|c|c|c|}
\hline \multirow[b]{2}{*}{$\begin{array}{l}\text { Soil, plant, and } \\
\text { ecosystem pools }\end{array}$} & \multicolumn{4}{|c|}{ Acclimating } & \multicolumn{4}{|c|}{ Non-acclimating } \\
\hline & Control & $\begin{array}{l}\text { Summer } \\
\text { warming }\end{array}$ & $\begin{array}{l}\text { Winter } \\
\text { warming }\end{array}$ & $\begin{array}{l}\text { Year-round } \\
\text { warming }\end{array}$ & Control & $\begin{array}{l}\text { Summer } \\
\text { warming }\end{array}$ & $\begin{array}{l}\text { Winter } \\
\text { warming }\end{array}$ & $\begin{array}{l}\text { Year-round } \\
\text { warming }\end{array}$ \\
\hline \multicolumn{9}{|l|}{ Soil pools } \\
\hline Polyphenolic SOM & 2803 & $2513(90)$ & $2656(95)$ & $2356(84)$ & 2663 & $2593(97)$ & $3438(129)$ & $2501(94)$ \\
\hline Holocellulose SOM & 2495 & $2499(100)$ & $1500(60)$ & $1968(79)$ & 2518 & $2375(94)$ & $2381(95)$ & $2186(87)$ \\
\hline N-rich SOM & 734 & $757(103)$ & $638(87)$ & $614(84)$ & 913 & $933(102)$ & $550(60)$ & $821(90)$ \\
\hline Total soil stocks & 6032 & $5769(96)$ & $4794(80)$ & $4938(82)$ & 6093 & $5900(97)$ & $6368(105)$ & $5508(90)$ \\
\hline Plant biomass & 554 & $680(123)$ & $711(128)$ & $886(160)$ & 376 & $405(108)$ & $636(169)$ & $578(154)$ \\
\hline Litter biomass & 128 & $157(123)$ & 164 (129) & $204(160)$ & 87 & $94(108)$ & $143(164)$ & $134(154)$ \\
\hline Ecosystem C (all pools) & 6714 & $6606(98)$ & $5669(84)$ & $6028(90)$ & 6556 & $6399(98)$ & 7147 (109) & $6220(95)$ \\
\hline
\end{tabular}

Note: The numbers in parentheses represent the percentage of specific pools relative to the control.

when the microbial biomass could shift its $C: N$ ratio to a new set point within one year.

\section{REsults AND Discussion}

\section{Ecosystem-level responses to warming and microbial acclimation}

We explored the effects of the interaction between the seasonality of warming and microbial acclimation potential on tundra ecosystem $\mathrm{C}$ storage dynamics over a 50-year period. Temperature limited decomposer activity and plant growth in the tundra, both directly and indirectly, by releasing more $\mathrm{N}$ with increased SOM turnover. Warming drove soil $\mathrm{C}$ loss and plant $\mathrm{C}$ gain across all model scenarios, although short-term (less than one decade) responses did not necessarily reflect long-term (50-year) C storage trajectories. For example, 50 years of winter warming ultimately drove a net increase in soil $\mathrm{C}$, despite initial losses in all three SOM pools. The seasonality of warming (summer vs. winter or year-round) had strongly divergent effects on the magnitude of soil C loss, with significantly lower loss under summer warming than winter warming. The ability of the microbial biomass to shift $\mathrm{C}: \mathrm{N}$ and enzyme allocation patterns between more bacteria-like and fungus-like characteristics in response to a changing soil environment also affected soil and ecosystem $\mathrm{C}$ storage trajectories, by increasing the efficiency by which SOM was decomposed.

Simulations under control conditions when the microbial community $\mathrm{C}: \mathrm{N}$ set point was fixed (i.e., "the non-acclimating microbial community") had lower baseline plant and microbial productivity than the corresponding acclimating community, although both communities yielded soil respiration and annual NPP values within reported ranges for Arctic tundra systems (Shaver and Chapin 1991, Melillo et al. 1993, Oechel et al. 1993). This difference in baseline conditions is caused because the non-acclimating community is less efficient than the acclimating community, including during the model spin-up period. Reflecting the fact that decomposer efficiency was greater when microbes could acclimate, total soil $\mathrm{C}$ loss (relative to their respective control conditions) was greater under all warming scenarios when the microbial biomass could acclimate than the corresponding non-acclimating scenarios.

The interaction between the seasonality of warming and the acclimation potential of the microbial community also affected net ecosystem $\mathrm{C}$ balance. Warming increased plant biomass in all scenarios, but this completely offset soil C losses only in the nonacclimating winter warming scenario. The balance between soil $\mathrm{C}$ loss and plant $\mathrm{C}$ gain (Table 1) reflects nonlinear coupling between seasonal shifts in microbial vs. plant demands for $\mathrm{N}$ with changing litter inputs to substrates.

\section{Microbial responses to the seasonality of warming}

Warming-driven increases in soil respiration tend to decline over time in field experiments (Luo et al. 2001, Melillo et al. 2002, Allison et al. 2010). A possible mechanism for this is that thermal stress reduces microbial CUE (Luo et al. 2001, Melillo et al. 2002, Allison et al. 2010). This reduced stimulation of soil respiration over time might also reflect a decline in available substrate pools (Kirschbaum 2004, Hartley et al. 2007, Rinnan et al. 2011). Under prolonged warming, if microbial CUE declines, biomass should do so as well, and so, ultimately, should extracellular enzyme pools, leading to reduced decomposition and respiration (Allison et al. 2010). However, our model suggests that using short-term effects of thermal stress on microbial CUE to infer long-term responses of soil respiration and ecosystem $\mathrm{C}$ dynamics is complicated when explicitly considering the coupled responses of plants, decomposers, and the soil environment to warming. In our simulations, the labile-C and N-rich SOM pools most sharply declined under winter and year-round warming in both the acclimating and non-acclimating communities (Table 1); soil respiration increased and then declined only under winter and year-round warming when the microbial biomass could acclimate, but under all scenarios when the microbes could not acclimate (Fig. 5).

Over 50 years of simulated warming, microbial CUE declined to $93 \%$ and $79 \%$ of control values for the year- 
Microbes can acclimate
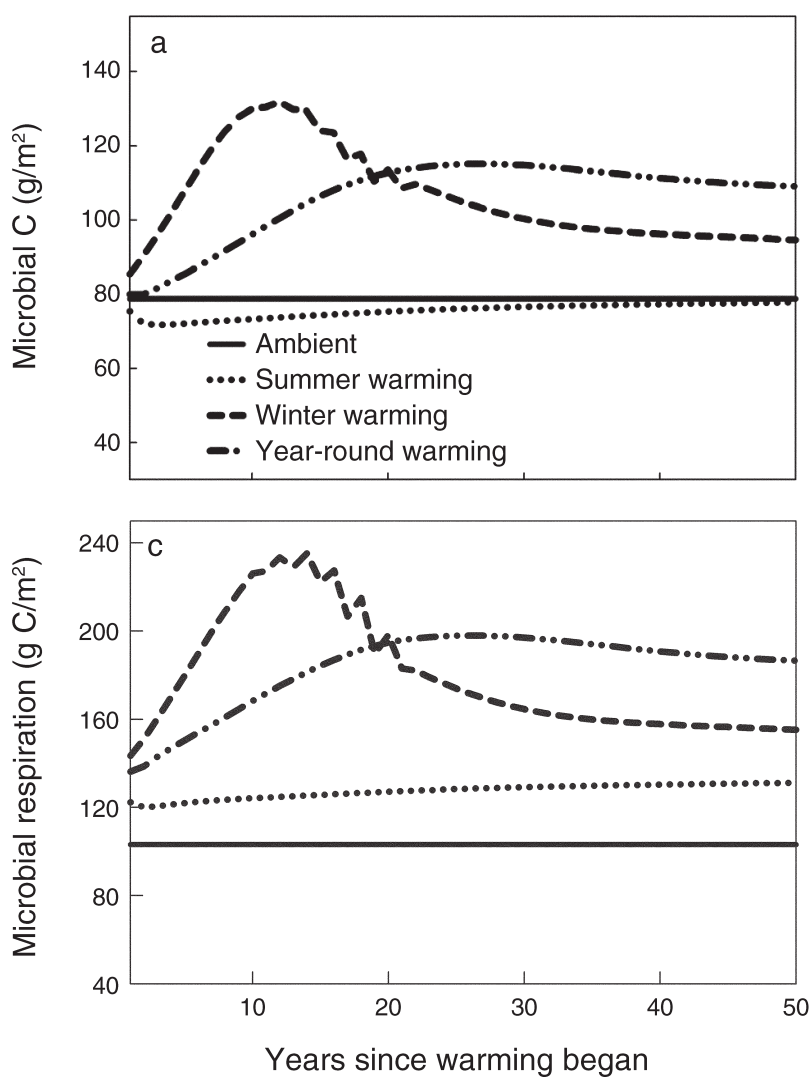

Microbes cannot acclimate
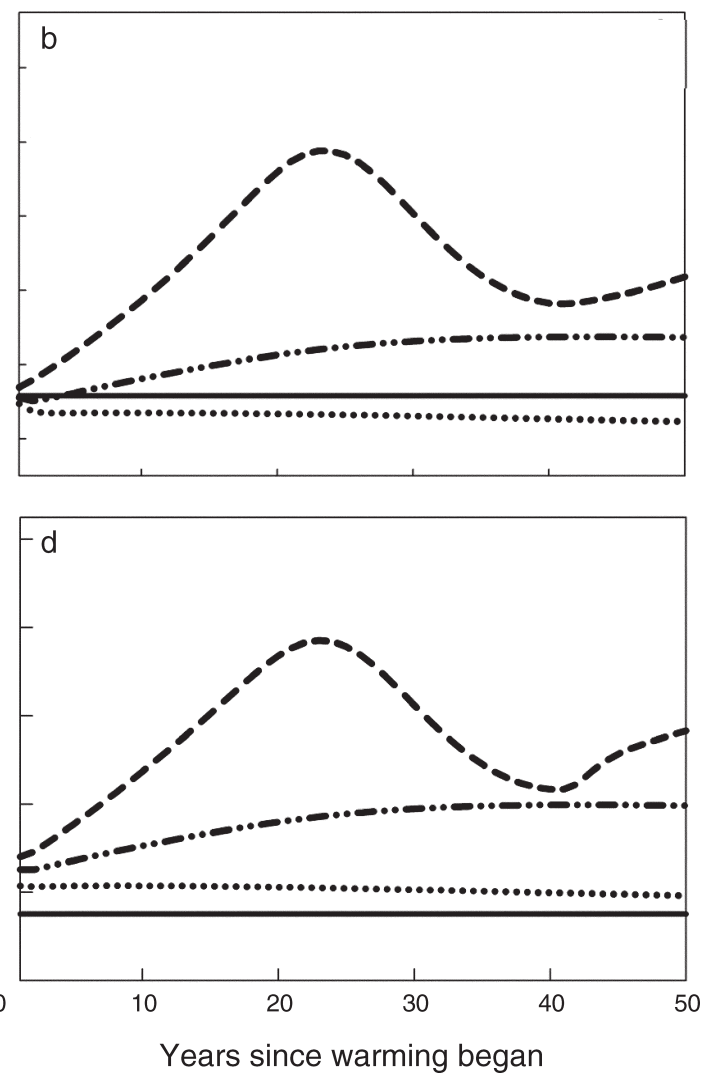

FIG. 5. Annual average (a, b) microbial biomass and (c, d) respiration over 50 years following the onset of warming. Left panels $(a, c)$ represent when the microbial biomass can acclimate its $C: N$ set point, and right panels $(b, d)$ represent when the microbial biomass $\mathrm{C}: \mathrm{N}$ set point is fixed.

round and winter warming acclimating scenarios and to $95 \%$ and $86 \%$ of control values for the non-acclimating scenarios. A sustained reduction in CUE, however, was not always correlated with a sustained decline in microbial biomass or soil respiration (Figs. 5 and 6). On a decadal time scale, microbial CUE tended to stabilize under soil warming, because higher temperatures increased the proportion of extracellular enzymes in the soil relative to microbial biomass over time, limiting the warming-driven depression of CUE (Fig. 6). Seasonality also affected the influence of warming on microbial CUE, and ultimately, ecosystem $\mathrm{C}$ storage dynamics. Under winter and year-round warming, for example, microbial resource uptake initially overcompensated for decreased CUE, driving microbial biomass and soil respiration to increase, despite lower CUE. Microbial biomass growth was initially the most stimulated by winter warming in both the acclimating and non-acclimating scenarios (and drove the largest soil $\mathrm{C}$ loss in the acclimating community). However, microbial growth rate in the acclimating scenario rapidly declined within 13 years following the onset of winter warming, reflecting the largest decline in CUE from control conditions.
Over a yearly time scale, the onset of growing season conditions (Fig. 4) decreased microbial CUE and biomass across all scenarios (Fig. 7a-d). This modeled effect, which is similar to empirically observed declines in decomposer activity observed during the transition from frozen to unfrozen soils at the onset of the tundra growing season (Wallenstein et al. 2009, Sistla and Schimel 2013), is driven by increased respiration costs relative to $\mathrm{C}$ uptake as soil temperature rises above freezing. Paradoxically, although growing season temperatures always decreased CUE relative to freezing soil temperatures, summer-only warming ultimately increased the yearly average microbial CUE relative to control conditions in both the acclimating and nonacclimating communities (by $2.5 \%$ and $2.8 \%$, respective1y; Fig. 7e, f). This pattern highlights the importance of the decoupling between extracellular enzyme activity and microbial biomass (Schimel and Weintraub 2003). Relatively more extracellular enzymes acting at higher rates of activity (due to warmer soil temperatures) stimulated DOC production in all of the acclimating warming scenarios, and in the non-acclimating community summer and year-round warming scenarios (Fig. 

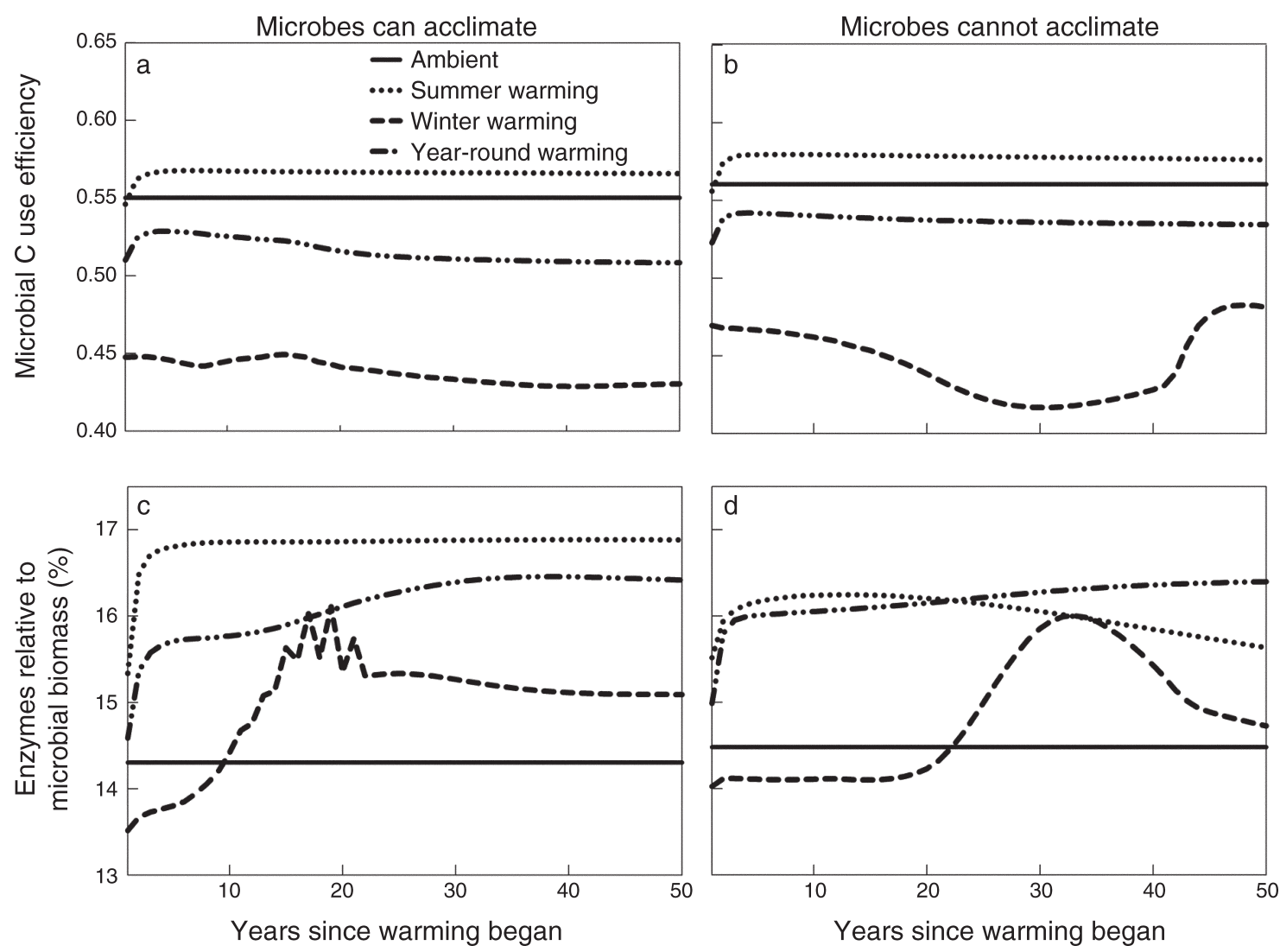

FIG. 6. ( $\mathrm{a}, \mathrm{b})$ Yearly average $\mathrm{C}$ use efficiency (CUE) and (c, d) percentage of extracellular enzymes relative to microbial biomass over 50 years of warming or ambient conditions for (left panels) acclimating and (right panels) non-acclimating microbial communities.

$7 \mathrm{~g}, \mathrm{~h})$, which offset a portion of the temperature-driven increases in microbial respiration $\mathrm{C}$ costs.

\section{Microbial $C: N$ and $N$ mineralization}

The effects of a fluctuating microbial biomass C:N cascade through the system, regulating $\mathrm{C}$ and $\mathrm{N}$ mineralization, enzyme allocation, decomposition, plant $\mathrm{N}$ uptake, and growth. Therefore under the control temperature scenario, soil, plant, and microbial pools vary when the system is allowed to equilibrate, with or without microbial acclimation potential. For example, when temperatures rise above freezing, the microbial $\mathrm{C}: \mathrm{N}$ of both the acclimating and non-acclimating community declines, because $\mathrm{C}$ mineralization and DOC consumption increases relative to microbial $\mathrm{N}$ uptake, causing DOC to crash at the onset of the growing season (Fig. 7g, h). Conversely, when soil temperature declines, microbial $\mathrm{C}: \mathrm{N}$ increases as respiration $\mathrm{C}$ costs diminish (Fig. 8a, b).

When the microbial community could not acclimate its $\mathrm{qMicB}^{*}$, its average $\mathrm{C}: \mathrm{N}$ was marginally greater (10.16) than the fixed target $\mathrm{C}: \mathrm{N}$ of 10 in the control scenario following model spin-up. All three warming scenarios changed the acclimating community's average
C:N by $<1 \%$ (Fig. 8 d). Fifty years of summer and winter warming slightly increased the average yearly C:N relative to the control (10.24 and 10.18, respectively), while year-round warming drove the average $\mathrm{C}: \mathrm{N}$ to be slightly lower than the control (10.12).

When the microbial community could acclimate, average control microbial $\mathrm{C}: \mathrm{N}$ increased to 10.26 following model spin-up. Summer warming drove the microbial community toward a $7 \%$ increase in average C:N (11.00; i.e., more fungal-like), similar to field observations of increasing $\mathrm{F}: \mathrm{B}$ dominance and greater fungal biomass in a long-term tundra summer warming field study (Clemmensen et al. 2006, Deslippe et al. 2012), while winter warming decreased average microbial C:N by $11 \%$ (to 9.13; i.e., more bacterial-like). Under year-round warming, the acclimating community's microbial C:N increased slightly (10.31; Fig. 8c). Increased $\mathrm{N}$ demand reduced gross $\mathrm{N}$ mineralization for the acclimating community under winter warming relative to control conditions, despite larger microbial biomass and accelerated decomposition. In contrast, when warming grew the non-acclimating microbial biomass, gross $\mathrm{N}$ mineralization also increased, regardless of the seasonality of the treatment (Fig. 9). 

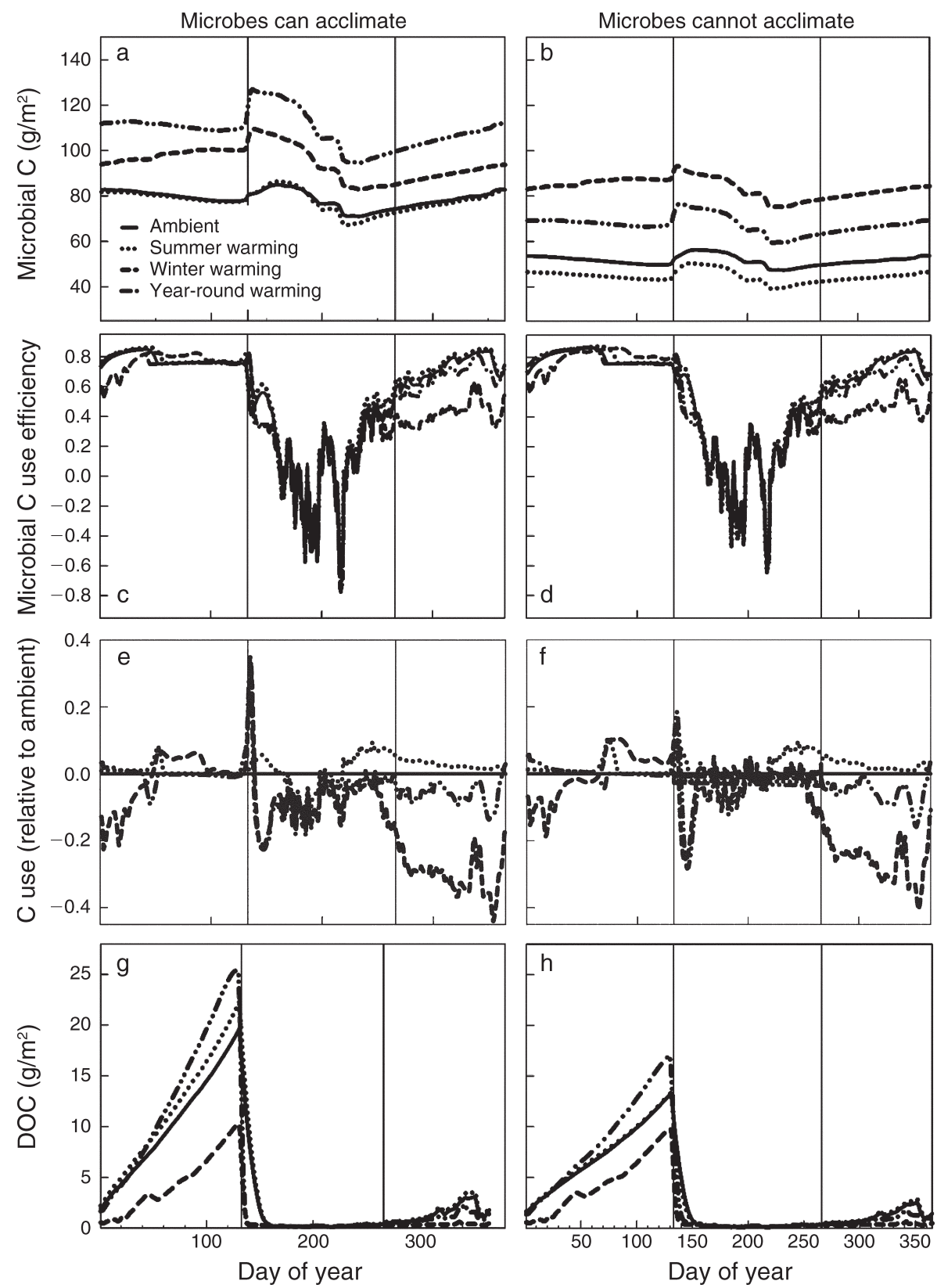

Fig. 7. (a, b) Daily microbial biomass, (c, d) C use efficiency (CUE), and (e, f) CUE relative to control conditions for one calendar year in the 50th year following the onset of warming. The left panels represent when the microbial biomass can acclimate its C:N set point, while the right panels represent the corresponding non-acclimating community. Vertical lines demarcate the plant growing season, when soil temperatures rise above $-1^{\circ} \mathrm{C}$. This transition period is correlated with an initial rise and subsequent rapid drop in both microbial biomass and CUE across all acclimation and climate scenarios (a-d). (e,f) The acclimating community tends to have a higher CUE than the non-acclimating community in all warming scenarios at the onset of the growing season and $(\mathrm{g}, \mathrm{h})$ greater dissolved organic carbon (DOC) production, reflecting that an acclimating community generates seasonally specific increases in microbial efficiency.

\section{Microbial extracellular enzyme allocation synthesis effort}

Enzyme allocation effort changed with warming (Fig. 10). In all cases, more than a third of extracellular enzyme synthesis effort was allocated toward the breakdown of holocellulose and carbohydrates. Winter warming drove the largest changes in extracellular enzyme synthesis under both acclimation scenarios: toward targeting the labile C, holocellulose SOM pool when the microbial biomass could acclimate, and toward first targeting the $\mathrm{N}$-rich SOM pool, rather than the lignocellulose SOM pool when it could not. This disproportionate effect of 

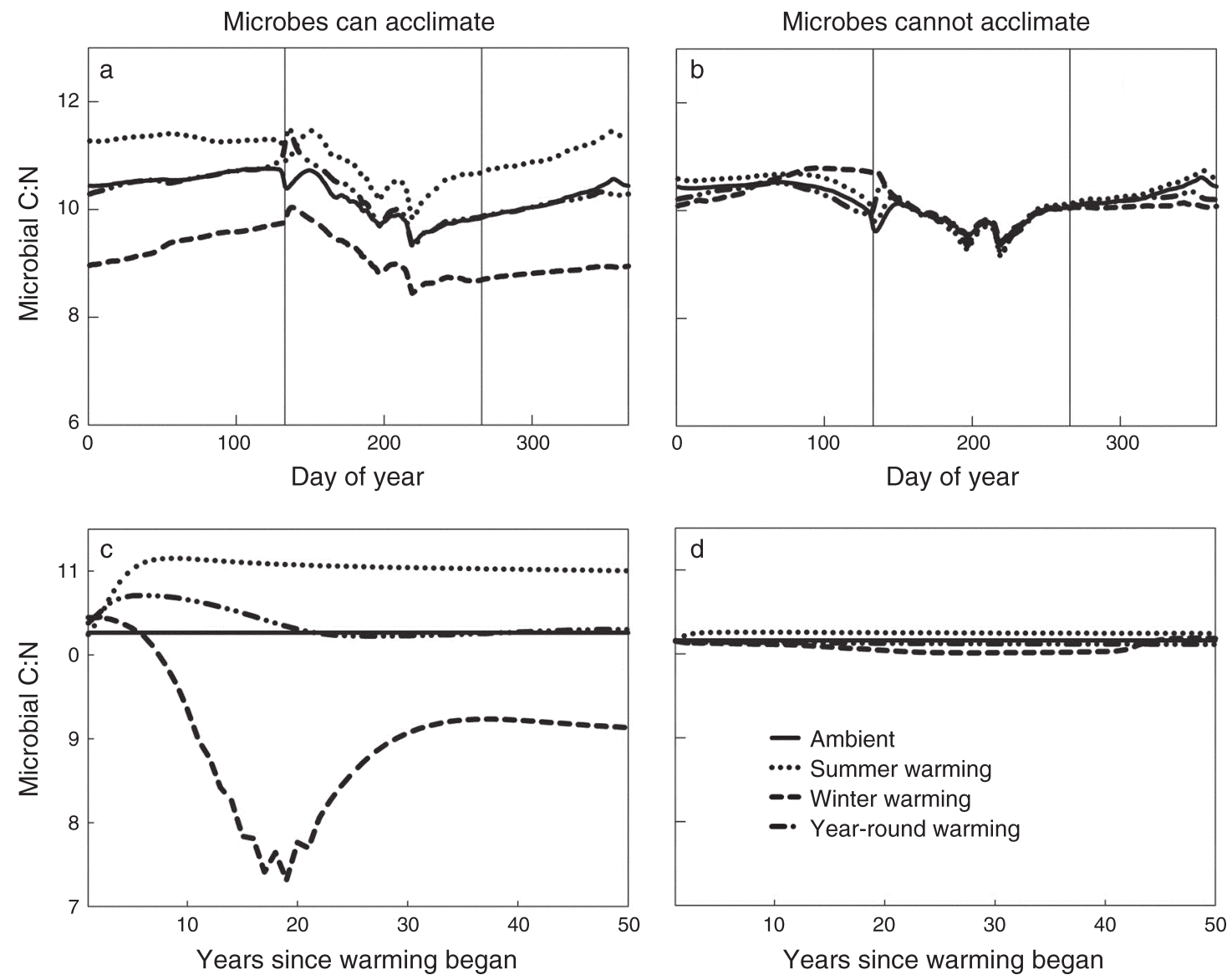

FIG. 8. (a, b) Daily microbial biomass C:N for one year in the 50th year following the onset of warming, and (c, d) average yearly microbial biomass $\mathrm{C}: \mathrm{N}$ over 50 years of warming. The left panels represent when the microbial biomass can acclimate its $\mathrm{C}: \mathrm{N}$ set point, while the right panels represent the corresponding non-acclimating community. Vertical lines in panels (a) and (b) demarcate the plant growing season, when soil temperatures rise above $-1^{\circ} \mathrm{C}$.
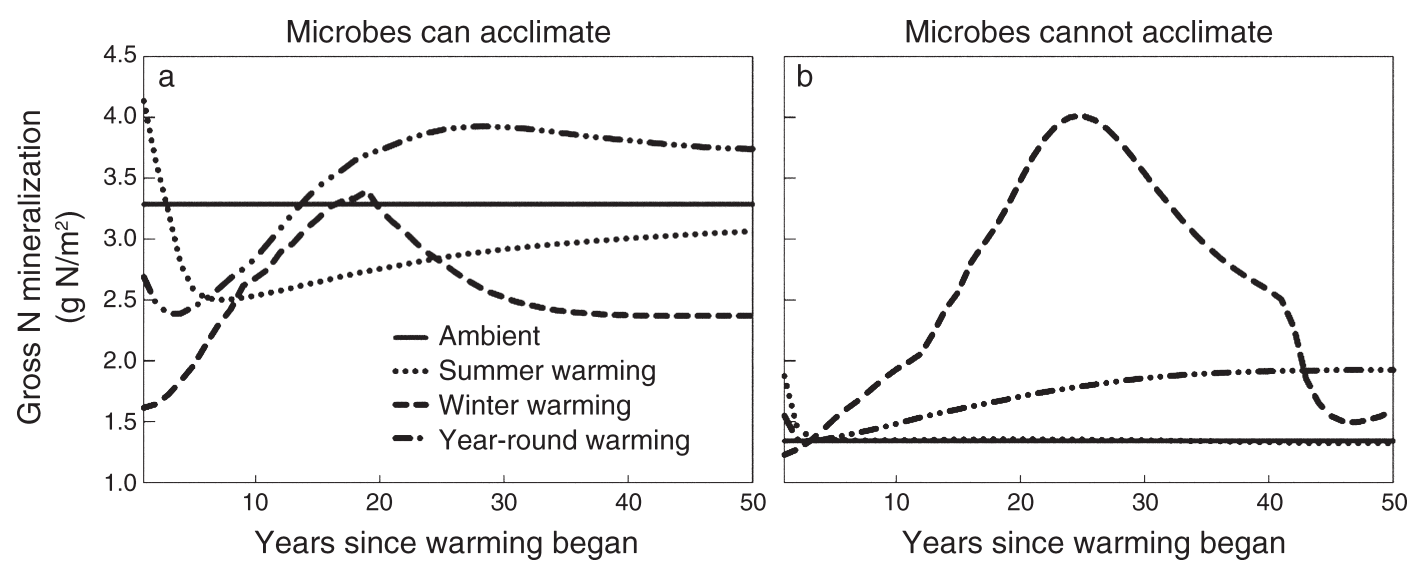

FIG. 9. Yearly total gross $\mathrm{N}$ mineralization over 50 years of warming or ambient conditions for (left) acclimating and (right) non-acclimating microbial communities. The ability to acclimate decreases gross $\mathrm{N}$ mineralization in response to warming relative to the non-acclimating scenarios, and under winter warming, drives opposing effects. Winter warming enhances $\mathrm{N}$ mineralization in the non-acclimating communities, while in the acclimating community, $\mathrm{N}$ mineralization is suppressed by the same treatment. 

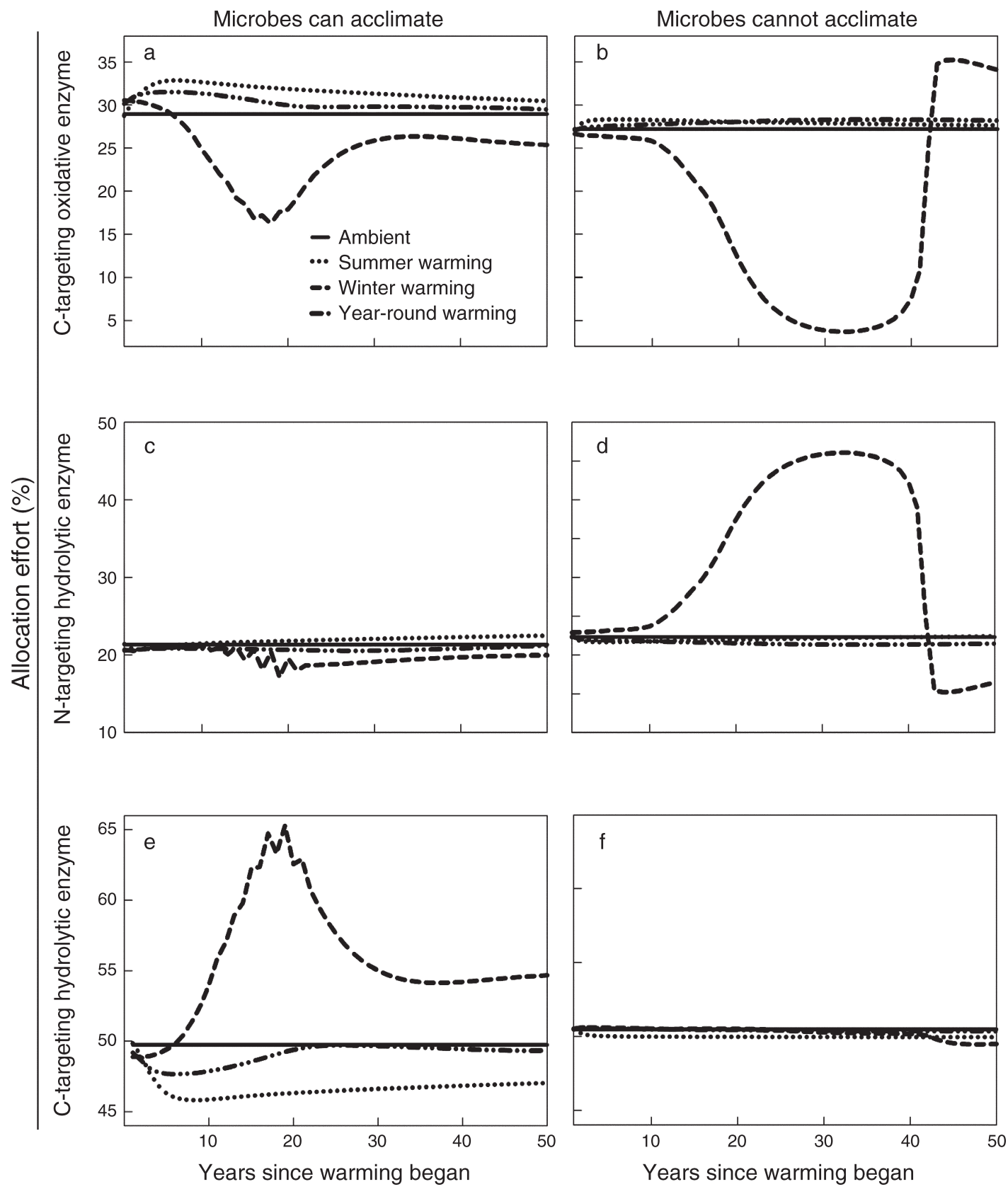

FIG. 10. Annual average extracellular enzyme synthesis effort over 50 years of warming or ambient conditions for (left) acclimating and (right) non-acclimating microbial communities. C-targeting oxidative enzymes break down the lignocellulose SOM pool, N-targeting hydrolytic enzymes break down the N-rich SOM pool, and C-targeting hydrolytic enzymes break down the Crich SOM pool.

winter warming on enzyme allocation reflects that winter warming caused the largest changes in DN:DOC (Supplement: Fig. S1), because $\mathrm{N}$ released from the SOM during the winter was not immediately available for plant uptake (while microbial C demand was increased). These effects cascaded through the system; regardless of decomposer acclimation ability, winter warming ultimately had the largest effect on the relative size of the three SOM pools (Table 1).
When the microbial community could acclimate, the seasonality of warming differently altered enzyme allocation patterns, both due to an altered soil environment and changes in the average microbial $\mathrm{C}: \mathrm{N}$. Summer warming increased allocation toward lignocellulose-targeting and $\mathrm{N}$-rich-targeting enzymes (105\% and $106 \%$ of control conditions in the 50th year of warming, respectively; Fig. 10a, c), at the expense of the hydrolytic C-targeting enzymes (95\% of control; Fig. 


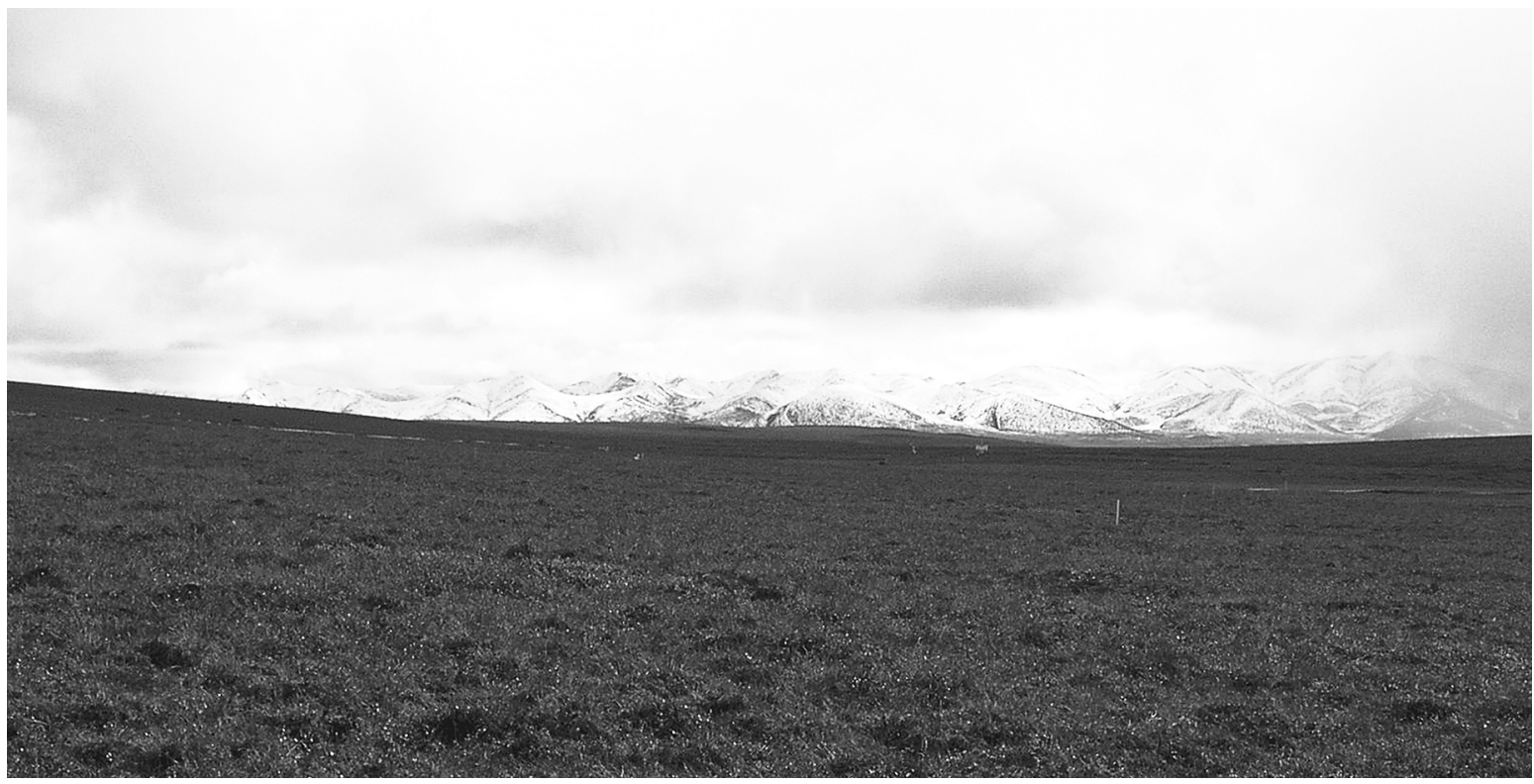

Plate 1. Tussock tundra near the Toolik Field Station, Alaska, USA. Photo credit: S. A. Sistla.

10e). This effect echoes those of two long-term summerwarming tundra studies that demonstrated increased dominance of recalcitrant-C-targeting, slow-growing bacteria and fungi, at the expense of more rapidly cycling communities (Rinnan et al. 2007, Deslippe et al. 2012). In contrast, simulated winter warming increased the acclimating community's allocation toward hydrolytic C-targeting extracellular enzymes (110\% of control; Fig. 10e), while lignocellulose-targeting oxidative (Fig. 10a) and N-rich-targeting hydrolytic (Fig. 10c) enzyme allocation effort declined ( $88 \%$ of control and $94 \%$ of control, respectively). Year-round warming had the smallest effect on shifting extracellular enzyme allocation, increasing allocation toward lignocellulose-targeting enzymes (102\% of control; Fig. 10a), while marginally down-regulating allocation toward the hydrolytic C-targeting (99\% of control; Fig. 10e) and Nrich-targeting ( $99 \%$ of control; Fig. 10c) enzymes.

When the microbial community could acclimate its $\mathrm{C}: \mathrm{N}$ target, shifts in enzyme allocation with warming increased the SOM decomposition rate under all warming cases. In contrast, although warming affected allocation to enzyme production in the non-acclimating case, because the microbial target $\mathrm{C}: \mathrm{N}$ was fixed and allocation was controlled primarily by the relative abundance of the SOM and DN: DOC pools, change in allocation did not respond consistently to warming. The non-acclimating microbial biomass growth was initially less responsive to warming than in the acclimating community. Summer and year-round warming had only a small effect on altering enzyme allocation patterns relative to the control $(<3.8 \%$ change after 50 years of warming relative to the control across enzymes; Fig. 10b, d, f), while winter warming increased and then rapidly decreased allocation effort toward N-richtargeting hydrolytic extracellular enzymes to $74 \%$ of the control, due to an increase in the DN: DOC pool (Fig. 10d; Appendix D: Fig. D1). The opposite pattern occurred for the non-acclimating community's lignocellulose oxidative enzyme allocation effort under winter warming, leading to a rapid mining of the N-rich SOM pool relative to the lignocellulose pool (Fig. 10b).

\section{Vegetation response to warming and microbial acclimation ability}

All warming treatments ultimately increased plant $\mathrm{N}$ uptake and growth (Fig. 11), which also increased litter inputs (Table 1). However, there was a lag in the winter warming treatment before the increase in overall ecosystem decomposition increased summertime $\mathrm{N}$ availability. The interaction of acclimation ability and the seasonality of warming strongly influenced the magnitude of plant response to warming. When the microbial biomass could acclimate (Fig. 11a, c), yearround warming promoted the largest increase in plant biomass ( $160 \%$ greater than control). Winter warming drove an initial decline in plant biomass, reflecting a decrease in available $\mathrm{N}$ as microbial $\mathrm{N}$ demand increased relative to availability. This was followed by rapid growth and subsequent decline in plant biomass over 50 years, paralleling microbial biomass growth (and therefore SOM decomposition). Summer warming had the smallest effect on change in total plant biomass (123\% greater than control). Relative to total initial plant biomass, warming grew average standing wood and root biomass more rapidly than leaf biomass, with year-round warming having the greatest effect after 50 years (increasing by $19 \%, 32 \%$, and $8 \%$, respectively). 

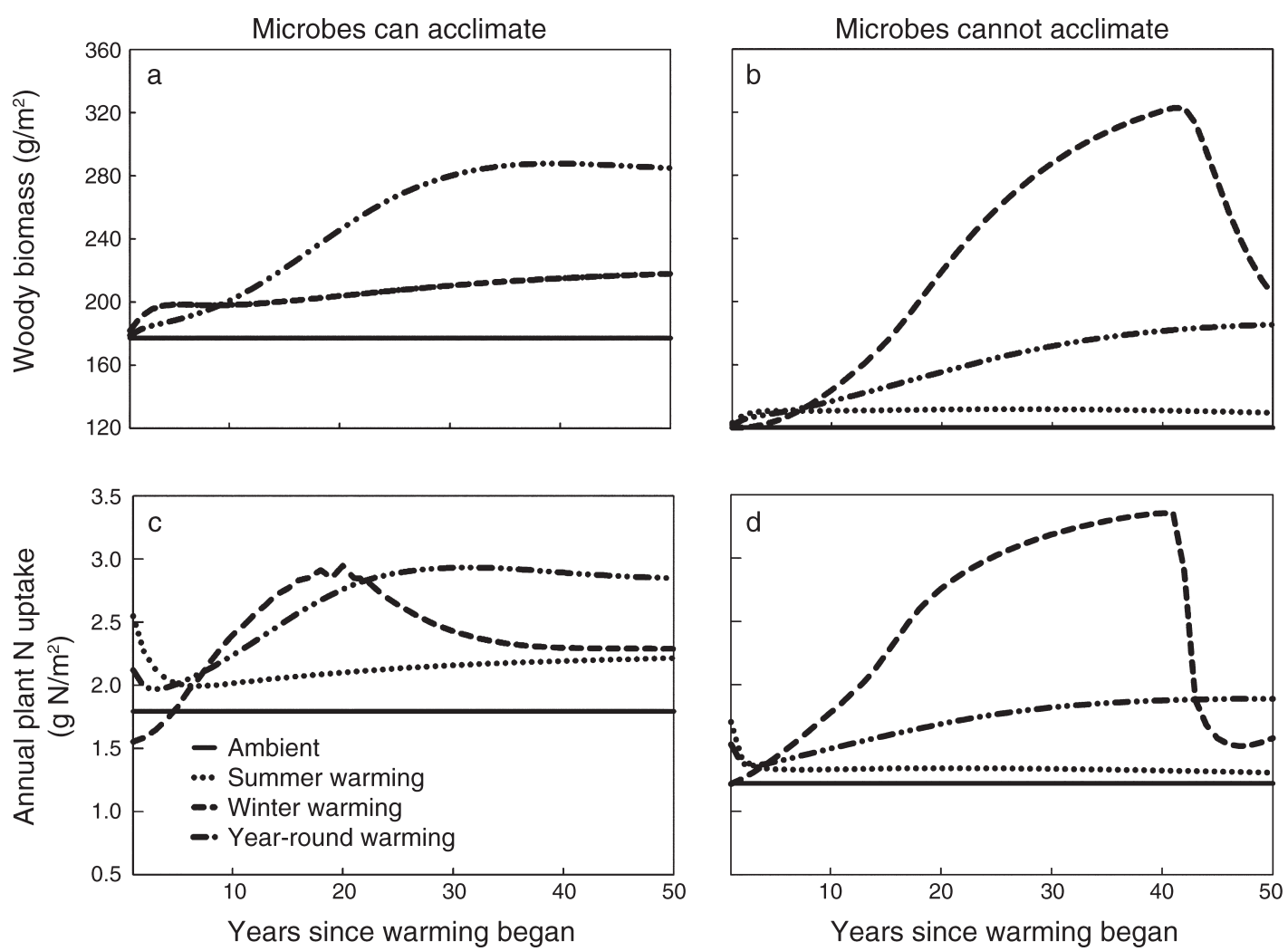

FIG. 11. (a, b) Annual average woody biomass and (c, d) plant $\mathrm{N}\left(\mathrm{NH}_{4}{ }^{+}\right.$and dissolved organic nitrogen [DON]) uptake over 50 years of warming or ambient conditions for (left) acclimating and (right) non-acclimating microbial communities.

Although the initial patterns of plant responses to warming were similar when the microbial biomass was unable to acclimate, winter warming drove the largest increase in plant biomass ( $169 \%$ greater than control), because plant-available $\mathrm{N}$ increased relative to the acclimating community (Fig. 11b, d). Notably, plant growth rapidly declined in the winter warming nonacclimating community scenario, coupled to a decline in microbial biomass (Fig. 5) and an increase in $\mathrm{OE}$ allocation effort as HNE allocation effort declined (Fig. 10). Year-round and summer warming had smaller effects on plant growth than winter warming, and than those of the comparable treatments with the acclimating community ( $154 \%$ and $108 \%$ greater than control, respectively). This difference was driven by the lower gross $\mathrm{N}$ mineralization and slower SOM decomposition rates than the acclimating community. Average standing wood and root biomass grew at a greater rate than leaf biomass, with winter warming dominating this effect (increasing by $22 \%, 39 \%$, and $8 \%$ relative to total initial plant biomass, respectively).

\section{The effects of warming and acclimation ability on SOM stocks}

Warming accelerated SOM decomposition, leading to a decline in total soil $\mathrm{C}$ stocks relative to the control in all scenarios except for the non-acclimating community under winter warming (Fig. 12; Appendix D: Fig. D2). Winter and year-round warming drove a greater soil C loss than summer warming, although plant litter inputs to the SOM also increased in these scenarios; the same phenomenon was observed in the non-acclimating community under year-round warming (Table 1). Overall, the acclimating microbial community drove proportionally more soil $\mathrm{C}$ loss than the non-acclimating community, despite also driving proportionally greater plant litter inputs under summer and year-round warming. Intriguingly, year-round and winter-only warming in the acclimating scenario promoted comparable soil $\mathrm{C}$ loss relative to control conditions over the 50 years of warming (Table 1). This phenomenon reflects the coupling of decomposer growth, plant growth, and litter inputs to the SOM. As the microbial biomass grew and decomposed more SOM, more $\mathrm{N}$ was released that was available for plant growth, increasing litter inputs to the soil and offsetting some of the loss of mineralized $\mathrm{C}$.

The extent to which the different SOM pools were targeted changed with both the seasonality of warming and microbial acclimation ability, reflecting the shifts in microbial extracellular enzyme allocation, C-, and Nmineralization dynamics. Winter warming decreased the average target $\mathrm{C}: \mathrm{N}$ of the acclimating community (Fig. 8), driving an initially rapid decomposition of the $\mathrm{N}$-rich 

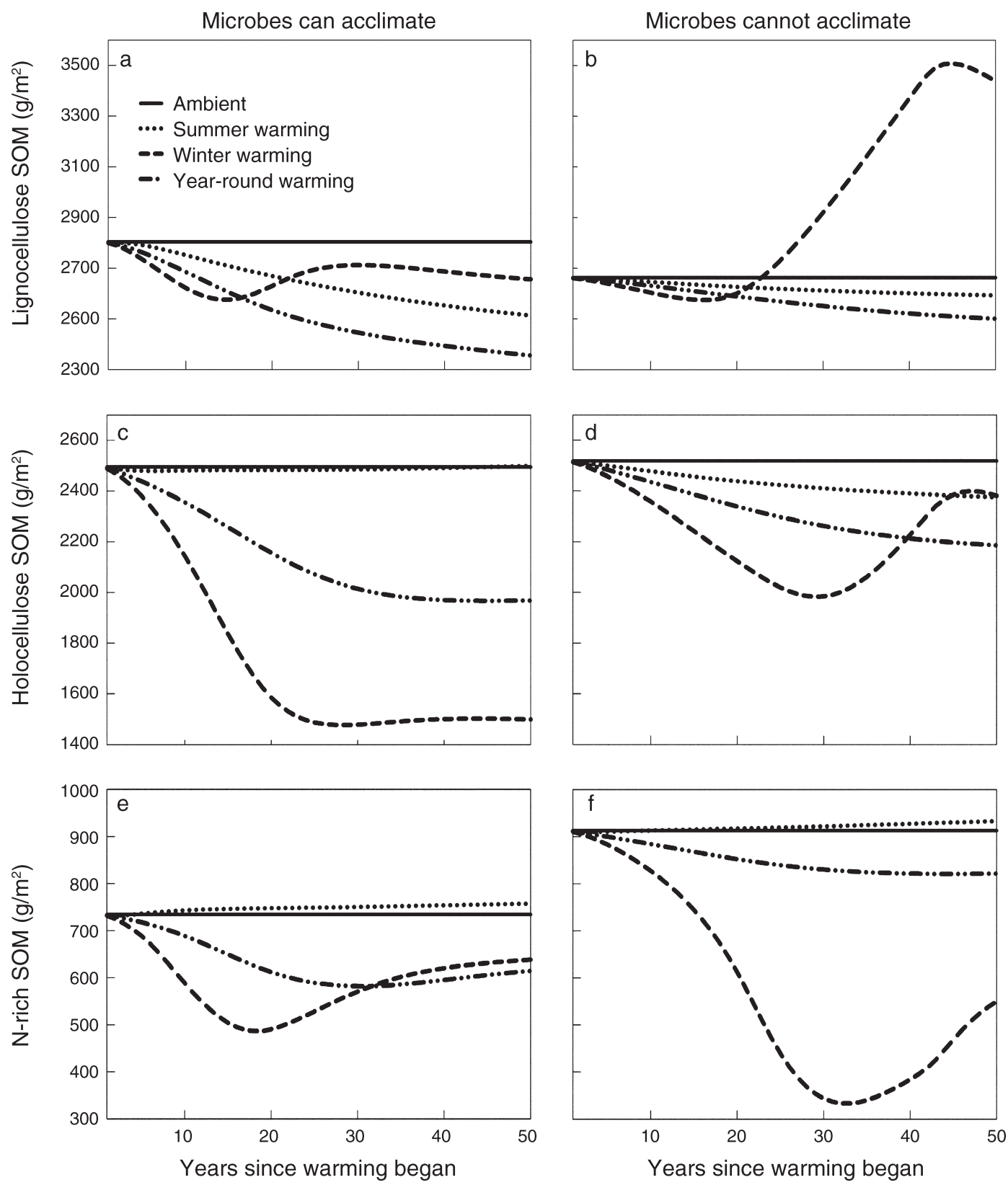

FIG. 12. Annual average soil organic matter (SOM) $\mathrm{C}$ for the three soil pools over 50 years of warming or ambient conditions for (left) acclimating and (right) non-acclimating microbial communities.

pool and increasing DN:DOC. To maintain the lower biomass $\mathrm{C}: \mathrm{N}$ with greater microbial biomass and higher respiration costs over time, however, the acclimating winter-warmed community tended to immobilize $\mathrm{N}$ and mine labile $\mathrm{C}$ from the holocellulose/carbohydrate SOM pool. In contrast, the $\mathrm{C}$ and $\mathrm{N}$ demands of the nonacclimating community under winter warming also increased as the microbial biomass grew (Fig. 8), but the higher average $\mathrm{C}: \mathrm{N}$ (due to the fixed qMicB*) stimulated both gross $\mathrm{N}$-mineralization, rapid mining of the labile N-rich SOM pool and, to a lesser extent, the holocellulose SOM pool. In contrast, the more recalcitrant polyphenolic SOM pool rapidly grew, causing a net increase in total soil $\mathrm{C}$.

Year-round warming (when decomposers could acclimate) drove significant SOM loss from the holocellulose/carbohydrate and N-rich SOM pools; however, year-round warming labile $\mathrm{C}$ mining loss was comparably smaller than winter warming in the acclimating scenario; this balance was offset by increased decomposer mining of the lignocellulose SOM pool. A similar pattern of $\mathrm{C}$ loss from each SOM pool was observed 
under year-round warming when decomposers could not acclimate; however, this loss was proportionally less than the corresponding acclimating warming scenario. Summer warming increased $\mathrm{C}$ demand relative to $\mathrm{N}$, thereby increasing the target $\mathrm{C}: \mathrm{N}$ of the acclimating community and stimulating lignocellulose SOM decomposition. In the non-acclimating community, the microbial biomass was unable to compensate for increased respiration costs with a fixed $\mathrm{qMicB} *$. Although net $\mathrm{C}$ loss from both C-rich SOM pools was observed in this scenario, the average microbial biomass and C-mineralization rate declined over the 50 years of summer warming (Figs. 5 and 12).

\section{CONCLUSION}

Both the seasonality of warming and the ability of the microbial community to acclimate its target biomass $\mathrm{C}: \mathrm{N}$ dramatically affected the $\mathrm{C}$ and $\mathrm{N}$ cycling dynamics of a modeled tundra system. To date, warming was documented to have caused significant soil C loss (which more than offset a coupled increase in plant C) only in a low-Arctic tundra system whose response to ambient, year-round climate warming was tracked for over a decade (Schuur et al. 2009, Allison et al. 2010). Not all tundra ecosystems, however, show acceleration of decomposition with warming. For example, more than a decade of experimental summer warming did not increase soil C-flux from a high-Arctic area (Lamb et al. 2011), and reduced bacterial growth in a subarctic heath site (Rinnan et al. 2007). Similarly, two decades of summer warming drove no net soil $\mathrm{C}$ loss from a low Arctic site, while increasing plant biomass, shrub cover, F:B, and recalcitrant $\mathrm{C}$-targeting decomposer dominance (Deslippe and Simard 2011, Deslippe et al. 2012, Sistla et al. 2013). Based on our model analysis, we hypothesize that the divergent tundra soil $\mathrm{C}$ storage trajectories observed might reflect the role of the seasonality of warming on the regulation of decomposer activity, and ultimately, net ecosystem C balance.

Modeled winter and year-round warming drove the greatest soil $\mathrm{C}$ loss, and ultimately sizeable ecosystem $\mathrm{C}$ loss when the microbial community could acclimate its biomass $\mathrm{C}: \mathrm{N}$, which in turn stimulated more fungal-like or bacterial-like enzyme production, nutrient demand, and turnover dynamics. In contrast, marked soil or ecosystem $\mathrm{C}$ loss was not observed under either summer warming scenario, highlighting the key role that the seasonal nature of warming might play in regulating tundra $\mathrm{C}$ storage trajectories over time (Schimel et al. 2004, Sturm et al. 2005, Hallinger et al. 2010, Natali et al. 2011). Although the onset of winter warming (and to a lesser extent year-round warming) drove a rapid increase in the acclimating microbial community's biomass and $\mathrm{C}$ mineralization, these initial ecosystem responses did not reflect long-term $\mathrm{C}$ storage trajectories under warming, as feedbacks between the plant and soil system stabilized decomposer growth relative to plant growth and litter inputs over time. Further, we observed that the acclimation ability of the decomposer community can strongly affect these feedbacks and net ecosystem $\mathrm{C}$ storage, as highlighted by the differences between the acclimating and non-acclimating community in controlling plant-available $\mathrm{N}$ (and ultimately ecosystem C stocks) under summer, year-round, and winter warming. These differences exemplify how (and under what mechanisms) alterations in microbial processes in a warming world might feed back to influence ecosystem function (Davidson and Janssens 2006).

The SCAMPS model provides a novel framework to explore how the acclimation potential of coupled plantsoil-decomposer systems can affect ecosystem responses to warming and other global change perturbations. As such, this model system may allow researchers to probe questions at the ecosystem scale in tundra systems and elsewhere that can be pragmatically tested in conjunction with manipulative field experiments. Such studies could include using SCAMPS to explore observed variation in the effects of warming or altered nutrient regimes on plant and microbial communities (e.g., Zhang et al. 2005, Wallenstein et al. 2006, 2007, Allison et al. 2007, Frey et al. 2008, Deslippe et al. 2011, 2012), or identifying mechanisms underlying divergent responses of similar ecotypes to warming (e.g., Shaver and Jonasson 1999, Schmidt et al. 2002). Because the SCAMPS model allows plant and decomposer communities to dynamically alter their shared soil environment, nutrient cycling dynamics, coupled to the structuring of biological communities, become emergent properties whose effects can be compared to ongoing empirical studies of systems under change.

\section{ACKNOWLEDGMENTS}

We thank B. Kwiatkowski for her help with model shell design. We also thank two anonymous reviewers, J. King, the INTERFACE workshop: How Do We Improve Earth System Models: Integrating Earth System Models, Ecosystem Models, Experiments and Long-Term Data, and the Schimel Lab group, whose comments greatly improved this study. This work was funded by a DOE Global Change Education Program Graduate Fellowship, the NOAA Climate and Global Change Postdoctoral Fellowship Program, and UCSB EEMB Block Grant to S. A. Sistla and NSF DEB 0919049 to E. B. Rastetter and J. P. Schimel, and Arctic LTER Project NSF-1026843.

\section{Literature Cited}

Alley, R., et al. 2007. Climate Change 2007: The physical science basis summary for policymakers contribution of Working Group I to the Fourth Assessment Report of the Intergovernmental Panel on Climate Change. Energy and environment. 18:21. Cambridge University Press, Cambridge, UK. http://dx.doi.org/ 10.1260/095830507781076194

Allison, S. D. 2006. Soil minerals and humic acids alter enzyme stability: implications for ecosystem processes. Biogeochemistry $81: 361-373$.

Allison, S. D., C. A. Hanson, and K. K. Treseder. 2007. Nitrogen fertilization reduces diversity and alters community structure of active fungi in boreal ecosystems. Soil Biology and Biochemistry 39:1878-1887.

Allison, S. D., and K. K. Treseder. 2011. Climate change feedbacks to microbial decomposition in boreal soils. Fungal Ecology 4:362-374. 
Allison, S. D., M. D. Wallenstein, and M. A. Bradford. 2010 Soil-carbon response to warming dependent on microbial physiology. Nature Geoscience 3:336-340.

Anisimov, O. A., D. G. Vaughan, T. V. Callaghan, C. Furgal, H. Marchant, T. D. Prowse, H. Vilhjálmsson, and J. E. Walsh. 2007. Polar regions (Arctic and Antarctic). Pages 653-685 in M. Parry, O. Canzaiani, J. Palutikof, P. Van der Linden, and C. Hanson, editors. Intergovernmental Panel on Climate Change. Working Group. Cambridge University Press, Cambridge, UK.

Arctic LTER Database. (n.d.). http://ecosystems.mbl.edu/arc/ terrest/terrestdata.html

Bardgett, R. D., C. Freeman, and N. J. Ostle. 2008. Microbial contributions to climate change through carbon cycle feedbacks. The ISME Journal 2:805-814.

Bossuyt, H., K. Denef, J. Six, S. Frey, R. Merck, and K. Paustian. 2001. Influence of microbial populations and residue quality on aggregate stability. Applied Soil Ecology 16:195-208.

Brant, J. B., E. W. Sulzman, and D. D. Myrold. 2006. Microbial community utilization of added carbon substrates in response to long-term carbon input manipulation. Soil Biology and Biochemistry 38:2219-2232.

Brantley, S. T., and D. R. Young. 2010. Shrub expansion stimulates soil $\mathrm{C}$ and $\mathrm{N}$ storage along a coastal soil chronosequence. Global Change Biology 16:2052-2061.

Bret-Harte, M. S., G. R. Shaver, and F. S. Chapin III. 2002. Primary and secondary stem growth in arctic shrubs: implications for community response to environmental change. Journal of Ecology 90:251-267.

Bunnell, F. L., and D. Tait. 1977. Microbial respiration and substrate weight loss. I. A general model of the influences of abiotic variables. Soil Biology and Biochemistry 9:33-40.

Bunnell, F. L., D. E. N. Tait, and P. W. Flanagan. 1977. Microbial respiration and substrate weight loss. II: A model of the influences of chemical composition. Soil Biology and Biochemistry 9:41-47.

Burns, R. G. 1982. Enzyme activity in soil: location and a possible role in microbial ecology. Soil Biology and Biochemistry 14:423-427.

Chapin, F. S., III. 1983. Direct and indirect effects of temperature on Arctic plants. Polar Biology 2:47-52.

Chapin, F. S., III., and G. R. Shaver. 1989. Differences in growth and nutrient use among arctic plant growth forms. Functional Ecology 3:73-80.

Chapin, F. S., III., G. R. Shaver, A. E. Giblin, K. J. Nadelhoffer, and J. A. Laundre. 2008. Responses of Arctic tundra to experimental and observed changes in climate. Ecology 76:694-711.

Clemmensen, K. E., A. Michelsen, S. Jonasson, and G. R. Shaver. 2006. Increased ectomycorrhizal fungal abundance after long-term fertilization and warming of two arctic tundra ecosystems. New Phytologist 171:391-404.

Curiel Yuste, J., D. D. Baldocchi, A. Gershenson, A. Goldstein, Misson, L. and S. Wong. 2007. Microbial soil respiration and its dependency on carbon inputs, soil temperature and moisture. Global Change Biology 13:2018-2035.

Cusack, D. F., M. S. Torn, W. H. McDowell, and W. L. Silver. 2010. The response of heterotrophic activity and carbon cycling to nitrogen additions and warming in two tropical soils. Global Change Biology 16:2555-2572.

Davidson, E. A., and I. A. Janssens. 2006. Temperature sensitivity of soil carbon decomposition and feedbacks to climate change. Nature 440:165-173.

Deslippe, J. R., M. Hartmann, W. W. Mohn, and S. W. Simard. 2011. Long-term experimental manipulation of climate alters the ectomycorrhizal community of Betula nana in Arctic tundra. Global Change Biology 17:1625-1636.

Deslippe, J. R., M. Hartmann, S. W. Simard, and W. W. Mohn. 2012. Long-term warming alters the composition of Arctic soil microbial communities. FEMS Microbiology Ecology 82:303-315.
Deslippe, J. R., and S. W. Simard. 2011. Below-ground carbon transfer among Betula nana may increase with warming in Arctic tundra. New Phytologist 192:689-698.

De Vries, F. T., E. Hoffland, N. van Eekeren, L. Brussaard, and J. Bloem. 2006. Fungal/bacterial ratios in grasslands with contrasting nitrogen management. Soil Biology and Biochemistry 38:2092-2103.

Ehrenfeld, J. G., B. Ravit, and K. Elgersma. 2005. Feedback in the plant-soil system. Annual Review of Environment and Resources 30:75-115.

Eliasson, P. E., R. E. McMurtrie, D. A. Pepper, M. Stromgren, S. Linder, and G. I. Agren. 2005. The response of heterotrophic $\mathrm{CO}_{2}$ flux to soil warming. Global Change Biology 11:167-181.

Elmendorf, S. C., et al. 2012. Plot-scale evidence of tundra vegetation change and links to recent summer warming. Nature Climate Change 2:453-457.

Epstein, H. E., M. D. Walker, F. S. Chapin, III, and A. M. Starfield. 2000. A transient, nutrient-based model of arctic plant community response to climatic warming. Ecological Applications 10:824-841.

Finzi, A. C., A. T. Austin, E. E. Cleland, S. D. Frey, B. Z. Houlton, and M. D. Wallenstein. 2011. Responses and feedbacks of coupled biogeochemical cycles to climate change: examples from terrestrial ecosystems. Frontiers in Ecology and the Environment 9:61-67.

Fontaine, S., A. Mariottib, and L. Abbadie. 2003. The priming effect of organic matter: a question of microbial competition? Soil Biology and Biochemistry 35:837-843.

Frey, S. D., R. Drijber, H. Smith, and J. Melillo. 2008. Microbial biomass, functional capacity, and community structure after 12 years of soil warming. Soil Biology and Biochemistry 40:2904-2907.

Frey, S., M. Knorr, J. Parrent, and R. Simpson. 2004. Chronic nitrogen enrichment affects the structure and function of the soil microbial community in temperate hardwood and pine forests. Forest Ecology and Management 196:159-171.

Giblin, A. E., K. J. Nadelhoffer, G. R. Shaver, J. A. Laundre, and A. J. McKerrow. 1991. Biogeochemical diversity along a riverside toposequence in Arctic Alaska. Ecological Monographs 61:415-435.

Hallinger, M., M. Manthey, and M. Wilmking. 2010. Establishing a missing link: warm summers and winter snow cover promote shrub expansion into alpine tundra in Scandinavia. New Phytologist 186:890-899.

Hartley, I. P., A. Heinemyer, and P. Ineson. 2007. Effects of three years of soil warming and shading on the rate of soil respiration: substrate availability and not thermal acclimation mediates observed response. Global Change Biology 13:1761-1770.

Hobbie, S. E. 1996. Temperature and plant species control over litter decomposition in Alaskan tundra. Ecological Monographs 66:503-522.

Hobbie, S. E., and F. S. Chapin, III. 1998. The response of tundra plant biomass, aboveground production, nitrogen, and $\mathrm{CO}_{2}$ flux to experimental warming. Ecology 79:15261544.

Jackson, R. B., H. A. Mooney, and E.-D. Schulze. 1997. A global budget for fine root biomass, surface area, and nutrient contents. Proceedings of the National Academy of Sciences USA 94:7362-7366.

Kielland, K. 1994. Amino acid absorption by Arctic plants: implications for plant nutrition and nitrogen cycling. Ecology 75:2373-2383.

Kirschbaum, M. U. F. 2004. Soil respiration under prolonged soil warming: Are rate reductions caused by acclimation or substrate loss? Global Change Biology 10:1870-1877.

Knorr, W., I. C. Prentice, J. I. House, and E. A. Holland. 2005. Long-term sensitivity of soil carbon turnover to warming. Nature 433:298-301.

Koven, C. D., B. Ringeval, P. Friedlingstein, P. Ciais, P. Cadule, D. Khvorostyanov, G. Krinner, and C. Tarnocai. 
2011. Permafrost carbon-climate feedbacks accelerate global warming. Proceedings of the National Academy of Sciences USA 108:14769-14774.

Kuhry, P., C.-L. Ping, E. A. G. Schuur, C. Tarnocai, and S. Zimov. 2009. Report from the International Permafrost Association: carbon pools in permafrost regions. Permafrost and Periglacial Processes 20:229-234

Lamb, E. G., S. Han, B. D. Lanoill, G. H. R. Henry, M. E. BrummellL, S. Banerjee, and S. D. Siciliano. 2011. A High Arctic soil ecosystem resists long-term environmental manipulations. Global Change Biology 17:3187-3194.

Lavoie, M., M. C. Mack, and E. A. G. Schuur. 2011. Effects of elevated nitrogen and temperature on carbon and nitrogen dynamics in Alaskan arctic and boreal soils. Journal of Geophysical Research 116:G03013. http://dx.doi.org/10. 1029/2010JG001629

Liao, J., and T. Boutton. 2008. Soil microbial biomass response to woody plant invasion of grassland. Soil Biology and Biochemistry 40:1207-1216.

Luo, Y. 2007. Terrestrial carbon-cycle feedback to climate warming. Annual Review of Ecology, Evolution, and Systematics 38:683-712.

Luo, Y., S. Wan, D. Hui, and L. L. Wallace. 2001. Acclimatization of soil respiration to warming in a tall grass prairie. Nature 413:622-625.

Mack, M. C., E. A. G. Schuur, M. S. Bret-Harte, G. R. Shaver, and F. S. Chapin III. 2004. Ecosystem carbon storage in arctic tundra reduced by long-term nutrient fertilization. Nature 431:440-443.

McKane, R. B., E. B. Rastetter, G. R. Shaver, K. J. Nadelhoffer, A. E. Giblin, J. A. Laundre, and F. S. Chapin III. 1997. Climatic effects on tundra carbon storage inferred from experimental data and a model. Ecology 78:1170-1187.

Melillo, J. M., A. D. McGuire, D. W. Kicklighter, B. Moore III, C. J. Vorosmarty, and A. Schloss. 1993. Global climate and terrestrial net primary production. Nature 363:234-240.

Melillo, J. M., P. A. Steudler, J. D. Aber, K. Newkirk, H. Lux, F. P. Bowles, C. Catricala, A. Magill, T. Ahrens, and S. Morrisseau. 2002. Soil warming and carbon-cycle feedbacks to the climate system. Science 298:2173-2176.

Mikan, C. J., J. P. Schimel, and A. P. Doyle. 2002. Temperature controls of microbial respiration in arctic tundra soils above and below freezing. Soil Biology and Biochemistry 34:17851795.

Moorhead, D. L., and J. F. Reynolds. 1993. Effects of climate change on decomposition in arctic tussock tundra: a modeling synthesis. Arctic and Alpine Research 25:403-412.

Moorhead, D. L., and R. L. Sinsabaugh. 2006. A theoretical model of litter decay and microbial interaction. Ecological Monographs 76:151-174.

Nadelhoffer, K. J., L. Johnson, J. Laundre, A. E. Giblin, and G. R. Shaver. 2002. Fine root production and nutrient content in wet and moist arctic tundras as influenced by chronic fertilization. Plant and Soil 242:107-113.

Näsholm, T., K. Kielland, and U. Ganeteg. 2009. Uptake of organic nitrogen by plants. New Phytologist 182:31-48.

Natali, S. M., E. A. G. Schuur, and R. L. Rubin. 2012. Increased plant productivity in Alaskan tundra as a result of experimental warming of soil and permafrost. Journal of Ecology 100:488-498.

Natali, S. M., E. A. G. Schuur, C. Trucco, C. E. Hicks Pries, K. G. Crummer, and A. F. Baron Lopez. 2011. Effects of experimental warming of air, soil and permafrost on carbon balance in Alaskan tundra. Global Change Biology 17:13941407.

Oades, J. M. 1984. Soil organic matter and structural stability: mechanisms and implications for management. Plant and Soil 76:319-337.

Oechel, W. C., S. J. Hastings, G. Vourlrtis, M. Jenkins, G. Riechers, and N. Grulke. 1993. Recent change of Arctic tundra ecosystems from a net carbon dioxide sink to a source. Nature 361:520-523.
Raich, J. W., and W. H. Schlesinger. 1992. The global carbon dioxide flux in soil respiration and its relationship to vegetation and climate. Tellus Series B-Chemical and Physical Meteorology 44:81-89.

Rastetter, E. B. 2011. Modeling coupled biogeochemical cycles. Frontiers in Ecology and the Environment 9:68-73.

Rastetter, E. B., G. I. Ågren, and G. R. Shaver. 1997. Responses of $\mathrm{N}$-limited ecosystems to increased $\mathrm{CO}_{2}$ : a balanced-nutrition, coupled-element-cycles model. Ecological Applications 7:444-460.

Rastetter, E. B., M. G. Ryan, G. R. Shaver, J. M. Melillo, K. J. Nadelhoffer, J. E. Hobbie, and J. D. Aber. 1991. A general biogeochemical model describing the responses of the $\mathrm{C}$ and $\mathrm{N}$ cycles in terrestrial ecosystems to changes in $\mathrm{CO}_{2}$, climate, and N deposition. Tree Physiology 9:101-126.

Rastetter, E. B., P. M. Vitousek, C. Field, G. R. Shaver, D. Herbert, and G. I. Ågren. 2001. Resource optimization and symbiotic nitrogen fixation. Ecosystems 4:369-388.

Rastetter, E. B., R. D. Yanai, R. Q. Thomas, M. A. Vadeboncoeur, T. J. Fahey, M. C. Fisk, B. L. Kwiatkowski, and S. P. Hamburg. 2013. Recovery from disturbance requires resynchronization of ecosystem nutrient cycles. Ecological Applications 23:621-642.

Resh, S. C., D. Binkley, and J. A. Parrotta. 2002. Greater soil carbon sequestration under nitrogen-fixing trees compared with eucalyptus species. Ecosystems 5:217-231.

Rinnan, R., A. Michelsen, and E. Bååth. 2011. Long-term warming of a subarctic heath decreases soil bacterial community growth but has no effects on its temperature adaptation. Applied Soil Ecology 47:217-220.

Rinnan, R., A. Michelsen, E. Bååth, and S. Jonasson. 2007. Fifteen years of climate change manipulations alter soil microbial communities in a subarctic heath ecosystem. Global Change Biology 13:28-39.

Romanovsky, V. E., C.-L. Ping, C. Seybold, and D. Harms. 2007. NRCS soils: Toolik, Alaska. http://soils.usda.gov/ survey/smst/alaska/Toolik/index.html

Rousk, J., and E. Bååth. 2011. Growth of saprotrophic fungi and bacteria in soil. FEMS Microbiology Ecology 78:17-30.

Schimel, J. P. 2001. Biogeochemical models: implicit versus explicit microbiology. Pages $177-183$ in E.-D. Schulze, M. Heimann, S. P. Harrison, E. Holland, J. Lloyd, I. C. Prentice, and D. S. Schimel, editors. Global biogeochemical cycles in the climate system. Elsevier, Amsterdam, The Netherlands.

Schimel, J. P., C. Bilbrough, and J. M. Welker. 2004. Increased snow depth affects microbial activity and nitrogen mineralization in two Arctic tundra communities. Soil Biology and Biochemistry 36:217-227.

Schimel, J. P., and S. M. Schaeffer. 2012. Microbial control over carbon cycling in soil. Frontiers in Microbiology 3:348.

Schimel, J. P., and M. N. Weintraub. 2003. The implications of exoenzyme activity on microbial carbon and nitrogen limitation in soil: a theoretical model. Soil Biology and Biochemistry 35:549-563.

Schmidt, I. K., S. Jonasson, G. R. Shaver, A. Michelsen, and A. Nordin. 2002. Mineralization and distribution of nutrients in plants and microbes in four arctic ecosystems: responses to warming. Plant and Soil 242:93-106.

Schmidt, M. W. I., et al. 2011. Persistence of soil organic matter as an ecosystem property. Nature 478:49-56.

Schuur, E. A. G., et al. 2008. Vulnerability of permafrost carbon to climate change: implications for the global carbon cycle. BioScience 58:701-714.

Schuur, E. A. G., J. G. Vogel, K. G. Crummer, H. Lee, J. O. Sickman, and T. E. Osterkamp. 2009. The effect of permafrost thaw on old carbon release and net carbon exchange from tundra. Nature 459:556-559.

Shaver, G. R., and F. S. Chapin, III. 1986. Effect of fertilizer on production and biomass of tussock tundra, Alaska, U.S.A. Arctic and Alpine Research 18:261-268. 
Shaver, G. R., and F. S. Chapin, III. 1991. Production: biomass relationships and element cycling in contrasting Arctic vegetation types. Ecological Monographs 61:1-31.

Shaver, G. R., and S. Jonasson. 1999. Response of Arctic ecosystems to climate change: results of long-term field experiments in Sweden and Alaska. Polar Research 18:245252.

Shaver, G. R., and J. A. Laundre. 2010. Arctic LTER data catalog. http://ecosystems.mbl.edu/arc/datacatalog.html

Sinsabaugh, R. L. 2010. Phenol oxidase, peroxidase and organic matter dynamics of soil. Soil Biology and Biochemistry 42:391-404.

Sinsabaugh, R. L., M. M. Carreiro, and D. A. Repert. 2002. Allocation of extracellular enzymatic activity in relation to litter composition, $\mathrm{N}$ deposition, and mass loss. Biogeochemistry 60:1-24.

Sinsabaugh, R. L., et al. 2008. Stoichiometry of soil enzyme activity at global scale. Ecology Letters 11:1252-1264.

Sinsabaugh, R. L., and D. L. Moorhead. 1994. Resource allocation to extracellular enzyme production: a model for nitrogen and phosphorus control of litter decomposition. Soil Biology and Biochemistry 26:1305-1311.

Sistla, S. A., S. Asao, and J. P. Schimel. 2012. Detecting microbial N-limitation in tussock tundra soil: implications for Arctic soil organic carbon cycling. Soil Biology and Biochemistry 55:78-84.

Sistla, S., J. C. Moore, R. Simpson, L. Gough, G. R. Shaver, and J. P. Schimel. 2013. Twenty years of tundra warming restructures plant and soil communities without changing overall soil carbon pools. Nature 497:615-618.

Sistla, S. A., and J. P. Schimel. 2012. Stoichiometric flexibility as a regulator of carbon and nutrient cycling in terrestrial ecosystems under change. New Phytologist 196:68-78.

Sistla, S., and J. P. Schimel. 2013. Seasonal patterns of microbial extracellular enzyme activities in an arctic tundra soil: identifying direct and indirect effects of long-term summer warming. Soil Biology and Biochemistry, in press.

Six, J., S. D. Frey, R. K. Thiet, and K. M. Batten. 2006. Bacterial and fungal contributions to carbon sequestration in agroecosystems. Soil Science Society of America Journal 70:555.

Strickland, M. S., and J. Rousk. 2010. Considering fungal:bacterial dominance in soils-methods, controls, and ecosystem implications. Soil Biology and Biochemistry 42:1385-1395.

Sturm, M., J. P. Schimel, G. Michaelson, J. M. Welker, S. F. Oberbauer, G. E. Liston, J. Fahnestock, and V. E. Romanovsky. 2005. Winter biological processes could help convert Arctic tundra to shrubland. BioScience 55:17-26.
Sullivan, P. F., M. Sommerkorn, H. M. Rueth, K. J. Nadelhoffer, G. R. Shaver, and J. M. Welker. 2007. Climate and species affect fine root production with long-term fertilization in acidic tussock tundra near Toolik Lake, Alaska. Oecologia 153:643-652.

Tarnocai, C., J. Canadell, E. Schuur, P. Kuhry, G. Mazhitova, and S. Zimov. 2009. Soil organic carbon pools in the northern circumpolar permafrost region. Global Biogeochemical Cycles 23. http://dx.doi.org/10.1029/2008GB003327

Treseder, K. K., et al. 2011. Integrating microbial ecology into ecosystem models: challenges and priorities. Biogeochemistry $1-12$.

Waldrop, M. P., and M. K. Firestone. 2006. Response of microbial community composition and function to soil climate change. Microbial Ecology 52:716-724.

Waldrop, M. P., and J. W. Harden. 2008. Interactive effects of wildfire and permafrost on microbial communities and soil processes in an Alaskan black spruce forest. Global Change Biology 14:2591-2602.

Waldrop, M. P., and D. R. Zak. 2006. Response of oxidative enzyme activities to nitrogen deposition affects soil concentrations of dissolved organic carbon. Ecosystems 9:921-933.

Wallenstein, M. D., S. McMahon, and J. Schimel. 2007. Bacterial and fungal community structure in Arctic tundra tussock and shrub soils. FEMS Microbiology Ecology 59:428-35.

Wallenstein, M. D., S. K. McMahon, and J. P. Schimel. 2009. Seasonal variation in enzyme activities and temperature sensitivities in Arctic tundra soils. Global Change Biology 15:1631-1639.

Wallenstein, M., S. McNulty, I. Fernandez, J. Boggs, and W. Schlesinger. 2006. Nitrogen fertilization decreases forest soil fungal and bacterial biomass in three long-term experiments. Forest Ecology and Management 222:459-468.

Wein, R. W., and L. C. Bliss. 1974. Primary production in Arctic cottongrass tussock tundra communities. Arctic and Alpine Research 6:261-274.

Weintraub, M. N., and J. P. Schimel. 2003. Interactions between carbon and nitrogen mineralization and soil organic matter chemistry in Arctic tundra soils. Ecosystems 6:129143.

Weintraub, M. N., and J. P. Schimel. 2005. Nitrogen cycling and the spread of shrubs control changes in the carbon balance of Arctic tundra ecosystems. BioScience 55:408-415.

Zhang, W., K. M. Parker, Y. Luo, S. Wan, L. L. Wallace, and S. Hu. 2005. Soil microbial responses to experimental warming and clipping in a tallgrass prairie. Global Change Biology 11:266-277.

\section{Supplemental Material}

Appendix A

Process equations described in the methods (Ecological Archives M084-008-A1).

\section{Appendix B}

Initial state variables (Ecological Archives M084-008-A2).

\section{Appendix C}

SCAMPS model parameters, processes represented in SCAMPS model, and full equations list (Ecological Archives M084-008-A3).

\section{Appendix D}

Figures of DN:DOC and total soil organic matter over 50 years of warming scenarios (Ecological Archives M084-008-A4). 